8

\title{
Health and Lifestyle Indicators in the European Union
}

\subsection{Prevalence of Overweight and Obesity}

\section{Background}

Overweight and obesity are known to be major risk factors for nutrition related chronic diseases such as type 2 diabetes, cardiovascular disease, hypertension and stroke. Energy intake that exceeds energy expenditure (a positive energy balance) leads to weight gain and so to overweight and obesity. As already described in the European Nutrition and Health Report 2004, in some countries the average energy intake decreases but prevalence of overweight and obesity is increasing. Thus, a more sedentary lifestyle causing less energy expenditure than the habitual energy intake might be the major factor responsible for increasing prevalence of overweight and obesity.

Overweight and obesity were assessed using the body mass index (BMI, $\mathrm{kg} / \mathrm{m}^{2}$ ). The World Health Organization [WHO, 2000] defines overweight in adults as a BMI $>25 \mathrm{~kg} / \mathrm{m}^{2}$ and obesity as a BMI $>30 \mathrm{~kg} / \mathrm{m}^{2}$.

As already mentioned in the European Nutrition and Health Report 2004, differences in the prevalence of overweight and obesity throughout different countries might be due to different methods of data collection. Therefore, results of calculations will be presented separately based on data derived from self-reported body height and body weight and data measured by trained staff, respectively. It has to be considered that it was not possible for all countries to calculate data for the same age groups. Differences in the prevalence of overweight and obesity could partly be due to this fact. Tables 8.18.3 give information on the included study populations. Another point to be kept in mind is the possibly different age distribution within the age groups that might have an influence on the mean BMI and prevalence of overweight and obesity in the countries.

For those countries, where the age groups did not fit perfectly to the predefined (4-6, $7-9,10-14,15-18,19-64,65+$ years), data were assigned to the most appropriate age groups. Exact data for age groups for the countries can be seen in the tables of the Annex.

\section{Prevalence of Overweight and Obesity in Children and Adolescents}

The calculated BMI changes considerably with age and is also dependent on sex. Because of the different cut-off points needed for the classification of body weight, 
Table 8.1. Study populations for assessment of overweight and obesity in children and adolescents (3-19 years) in the participating countries. Self-reported: $n=23,517$ from 9 countries; measured: $n=119,669$ from 14 countries

\begin{tabular}{lll}
\hline Country & Reference/survey name & Participants, $n$ \\
\cline { 1 - 1 } & female male \\
\hline
\end{tabular}

\section{Self-reported}

\begin{tabular}{|c|c|c|c|c|}
\hline Austria & Austrian Study on Nutritional Status (ASNS) & 177 & 233 & $10-14$ \\
\hline & Austrian Study on Nutritional Status (ASNS) & 1,021 & 1,129 & $15-18$ \\
\hline Belgium & Food Consumption Survey, Belgium, 2004 & 1,623 & 1,626 & $15-18$ \\
\hline \multirow[t]{4}{*}{ Denmark } & $\begin{array}{l}\text { Danish National Survey on Dietary Habits and Physical } \\
\text { Activity }\end{array}$ & 114 & 113 & $4-6$ \\
\hline & $\begin{array}{l}\text { Danish National Survey on Dietary Habits and Physical } \\
\text { Activity }\end{array}$ & 114 & 136 & $7-9$ \\
\hline & $\begin{array}{l}\text { Danish National Survey on Dietary Habits and Physical } \\
\text { Activity }\end{array}$ & 158 & 166 & $10-14$ \\
\hline & $\begin{array}{l}\text { Danish National Survey on Dietary Habits and Physical } \\
\text { Activity }\end{array}$ & 120 & 78 & $15-18$ \\
\hline Estonia & Eesti Kooliõpilaste Tervisekäitumise Uuring, 2005/2006 & 2,134 & 2,070 & $10-14,15-18$ \\
\hline Italy & $\begin{array}{l}\text { Health Behavior in School-Aged Children (HBSC), } \\
\text { international report from the } 2005 / 2006 \text { survey }\end{array}$ & 1,946 & 1,974 & $11-15$ \\
\hline Latvia & $\begin{array}{l}\text { Health Behavior in School-Aged Children (HBSC), } \\
\text { international report from the 2005/2006 survey }\end{array}$ & 1,778 & 1,790 & $11-15$ \\
\hline \multirow[t]{3}{*}{ Lithuania } & \multirow{2}{*}{$\begin{array}{l}\text { Health Behavior in School-Aged Children (HBSC), } \\
\text { international report from the } 2005 / 2006 \text { survey }\end{array}$} & 552 & 532 & 11 \\
\hline & & 626 & 656 & 13 \\
\hline & $\begin{array}{l}\text { Health Behavior in School-Aged Children (HBSC), } \\
\text { international report from the } 2005 / 2006 \text { survey }\end{array}$ & 754 & 716 & 15 \\
\hline Norway & UNGKOST 2000 & n.a. & n.a. & $4-14$ \\
\hline Sweden & $\begin{array}{l}\text { Dietary habits and nutrient intake in Swedish 4-year-old } \\
\text { children and schoolchildren in grade } 2 \text { and 5. Riksmaten } \\
\text { [Enghardt et al., 2006] }\end{array}$ & 611 & 570 & $4-14$ \\
\hline
\end{tabular}

\section{Measured $^{2}$}

\begin{tabular}{lllll}
\hline Austria & Austrian Study on Nutritional Status (ASNS) & 469 & 512 & $7-14$ \\
\hline Belgium & Flemish Growth Charts, Flanders, 2004 & 9,186 & 8,864 & $4-18$ \\
\hline France & French Nutrition and Health Survey (ENNS), 2006-2007 & 2,273 & 1,604 & $4-14$ \\
\hline Germany & $\begin{array}{l}\text { German Health Interview and Examination Survey for } \\
\text { Children and Adolescents, 2003-2006 }\end{array}$ & 7,267 & 7,569 & $3-17$ \\
\hline Greece & Kosti et al. [2008b] & 987 & 1,021 & $12-17$ \\
\hline
\end{tabular}


Table 8.1. Continued

\begin{tabular}{|c|c|c|c|c|}
\hline \multirow[t]{2}{*}{ Country } & \multirow[t]{2}{*}{ Reference/survey name } & \multicolumn{2}{|c|}{ Participants, $n$} & \multirow[t]{2}{*}{ Age, years } \\
\hline & & female & male & \\
\hline \multirow[t]{2}{*}{ Hungary } & $\begin{array}{l}\text { Representative Survey in Metropolitan Primary and } \\
\text { Secondary Schools in 2005-2006 }\end{array}$ & 927 & 1,003 & $7-14$ \\
\hline & $\begin{array}{l}\text { Representative Survey in Metropolitan Primary and } \\
\text { Secondary Schools in 2005-2006 }\end{array}$ & 603 & 670 & $15-19$ \\
\hline Italy & Okkio alla salute & 21,692 & 23,019 & $8-9$ \\
\hline Latvia & $\begin{array}{l}\text { Liekās kermeña masas un aptaukošanās problēma Latvijas } \\
\text { skolēniem (overweight and obesity problem in Latvian } \\
\text { schoolchildren) }\end{array}$ & 6,486 & 6,593 & $7-17$ \\
\hline Poland & $\begin{array}{l}\text { Household Food Consumption and Anthropometric Survey, } \\
2000\end{array}$ & 559 & 541 & $3-18$ \\
\hline \multirow[t]{3}{*}{ Portugal } & $\begin{array}{l}\text { Estado nutricional de crianças e oferta alimentar do pré- } \\
\text { escolar do município de Coimbra, Portugal, } 2001\end{array}$ & 1,190 & 1,210 & $3-6$ \\
\hline & $\begin{array}{l}\text { Prevalence of overweight and obesity in 7- to 9-year-old } \\
\text { Portuguese children: trends in BMI from } 1970 \text { to } 2002\end{array}$ & 2,274 & 2,237 & $7-9$ \\
\hline & $\begin{array}{l}\text { Family and school determinants of overweight in 13-year- } \\
\text { old Portuguese adolescents; Uso de tabaco em } \\
\text { adolescentes portugueses de } 13 \text { anos }\end{array}$ & 1,053 & 987 & 13 \\
\hline Slovenia & Fidler Mis et al.: Dietary intake of Slovenian adolescents & 1,214 & 1,010 & $15-18$ \\
\hline Spain & Catalan Nutrition Survey (ENCAT), 2002-2003 & 103 & 124 & $10-18$ \\
\hline The Netherlands & DNFCS, young children, 2005/06 & 312 & 327 & $4-6$ \\
\hline $\mathrm{UK}^{3}$ & Health Surveys for England, 2006 & 2,806 & 2,977 & $0-15$ \\
\hline \multicolumn{5}{|c|}{$\begin{array}{l}\text { 1 Body weight and body height reported by the participants. } \\
{ }^{2} \text { Body weight and body height measured by researchers. } \\
{ }^{3} \text { UK national BMI classification. }\end{array}$} \\
\hline
\end{tabular}

a general definition of overweight and obesity for children and adolescents cannot be used. The applied methods led to establishing cut-off points to define overweight and obesity in the studied children population in a defined region. Therefore, they result in considerably diverging prevalence of overweight and obesity [Freisling and Elmadfa, 2007]. For international comparability, the cut-off points by Cole et al. [2000] are recommended and therefore applied in all countries except for the United Kingdom (UK National BMI percentiles classification). Fig. 8.1 shows the prevalence of overweight and obesity in children and adolescents from the participating European countries. Data are presented ordered by age groups. 


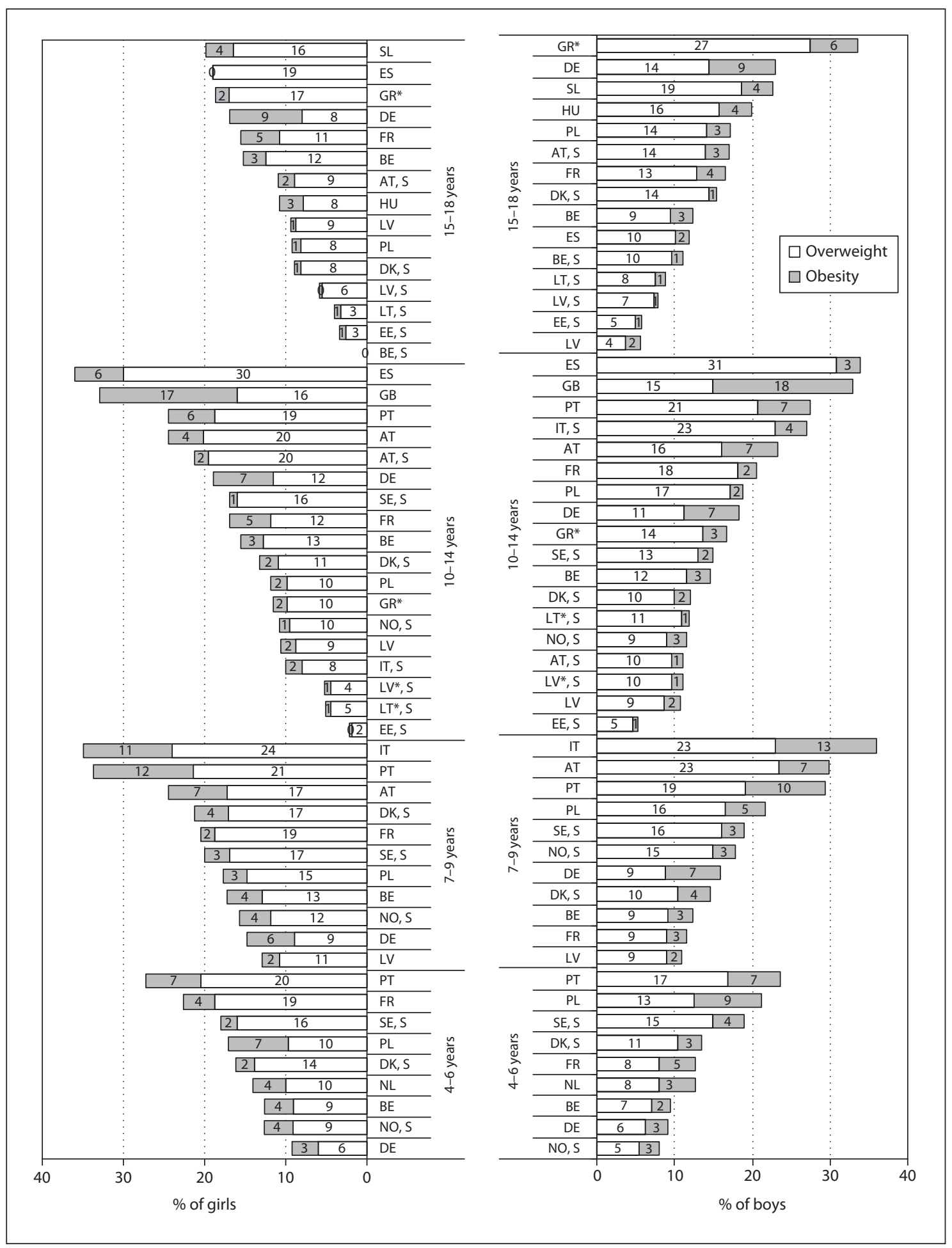

Fig. 8.1. Overweight and obesity in European children and adolescents of different age subgroups $(4-6,7-9,10-14,15-18$ years). S = BMl calculated from self-reported height and weight. Classification according to Cole et al. [2000]. *Estimated from mean values for different age groups. 
Table 8.2. Study populations for assessment of overweight and obesity in adults (19-64 years) in the participating countries. Self-reported: $n=86,936$ from 14 countries; measured: $n=73,926$ from 14 countries

Country Survey name $\quad \frac{\text { Participants, } n}{\text { female male }}$

\section{Self-reported}

\begin{tabular}{|c|c|c|c|c|}
\hline Austria & Austrian Study on Nutritional Status (ASNS) & 1,438 & 834 & $19-64$ \\
\hline Belgium & Food Consumption Survey, Belgium, 2004 & 1,623 & 1,626 & $19-63$ \\
\hline Denmark & $\begin{array}{l}\text { Danish National Survey on Dietary Habits and Physical } \\
\text { Activity }\end{array}$ & 2,124 & 1,936 & $19-64$ \\
\hline Estonia & Estonian Health Interview Survey, 2006 & 3,114 & 2,872 & $19-63$ \\
\hline Germany & National Telephone Health Survey (GSTeL03), 2004 & 4,302 & 4,016 & $18-65$ \\
\hline Hungary & 3rd Hungarian Nutrition Survey, 2003-2004 & 706 & 473 & $18+$ \\
\hline Ireland & Survey of Lifestyle, Attitudes and Nutrition, 2007 & 3,960 & 4,178 & $18-64$ \\
\hline Italy & Health-for-All (ISTAT, updated 2009) & n.a. & n.a. & $18+$ \\
\hline Lithuania & Health behavior among Lithuanian adult population, 2006 & 1,002 & 705 & $20-64$ \\
\hline Norway & Norkost, 1997 & n.a. & n.a & $19-63$ \\
\hline Poland & Low income & 200 & 40 & $19-63$ \\
\hline Portugal & $\begin{array}{l}\text { Data computed from the database of the Inquérito nacional } \\
\text { de saúde, 2005-2006. INE, INSA. }\end{array}$ & 21,299 & 19,894 & $20-64$ \\
\hline Sweden & $\begin{array}{l}\text { National public health survey. Health on equal terms? } 2007 \\
\text { National Institute of Public Health, Sweden }\end{array}$ & 2,329 & 1,824 & $19-64$ \\
\hline The Netherlands & CBS Statline, 2007 & 3,240 & 3,201 & $19-65$ \\
\hline \multicolumn{5}{|l|}{ Measured $^{2}$} \\
\hline Cyprus & CyDA 1st Epidemiological Study & 256 & 187 & $19-64$ \\
\hline Czech Republic & n.a. ${ }^{3}$ & 1,090 & 1,039 & $25-64$ \\
\hline Finland & FINRISK, 2007. Lääkärilehti, 2008 & 3,979 & 3,984 & $19-64$ \\
\hline France & French Nutrition and Health Survey (ENNS), 2006-2007 & 2,273 & 1,604 & $19-64$ \\
\hline Germany & German Nutrition Survey II, 2005-2007 & 5,544 & 4,625 & $19-64$ \\
\hline Greece & EPIC study, 1994-1999 & 12,034 & 8,365 & $19-64$ \\
\hline Ireland & Survey of Lifestyle, Attitudes and Nutrition 2007 & 891 & 949 & $19-64$ \\
\hline Latvia & Nutrition and Lifestyle in the Baltic Republics & 1,230 & 1,062 & $19-64$ \\
\hline Lithuania & National Nutrition Survey & 1,087 & 849 & $19-64$ \\
\hline Poland & $\begin{array}{l}\text { Household Food Consumption and Anthropometric Survey } \\
2000\end{array}$ & 1,469 & 1,346 & $18-64$ \\
\hline
\end{tabular}


Table 8.2. Continued

\begin{tabular}{|c|c|c|c|c|}
\hline \multirow[t]{2}{*}{ Country } & \multirow[t]{2}{*}{ Survey name } & \multicolumn{2}{|c|}{ Participants, n } & \multirow[t]{2}{*}{ Age, years } \\
\hline & & female & male & \\
\hline Portugal & $\begin{array}{l}\text { Overweight and obesity in Portugal: national prevalence in } \\
2003-2005\end{array}$ & 4,320 & 3,796 & $19-64$ \\
\hline Romania & National synthesis, 2006 & 341 & 177 & $19-64$ \\
\hline Spain & Catalan Nutrition Survey (ENCAT), 2002-2003 & 793 & 663 & $19-64$ \\
\hline UK & Health Surveys for England, 2006 & 4,925 & 5,048 & $19-64$ \\
\hline $\begin{array}{l}{ }^{1} \text { Body we } \\
{ }^{2} \text { Body we } \\
{ }^{3} \text { Informat }\end{array}$ & $\begin{array}{l}\text { body height reported by the participants. } \\
\text { body height measured by researchers. } \\
\text { e partner organization of the Czech Republic. }\end{array}$ & & & \\
\hline
\end{tabular}

The prevalence of overweight and obesity was already high in young children. For example in 4- to 6-year-old girls it ranged from 9 to $27 \%$, in 4 - to 6-year-old boys from 8 to $24 \%$. The highest prevalence was found in Spanish 10- to 14-year-old girls and 7 - to 9-year-old Italian boys (36\%). The prevalence of overweight and obesity derived from self-reported data tend to be considerably lower than data derived from measured body height and weight; for example in 10- to 14-year-old girls the highest prevalence derived by self-reported data was 22\% (Austria), whereas it was 36\% (Spain) derived from measured data.

\section{BMI, Overweight and Obesity in Adults}

Table 8.4 shows the mean BMI for European countries. The mean BMI was generally lower in women than in men except for Greece and Latvia. The lowest mean BMI was found for Hungarian 18 - to 34 -year-old women $\left(22.9 \mathrm{~kg} / \mathrm{m}^{2}\right.$, self-reported data), the highest for Greek women $\left(28.6 \mathrm{~kg} / \mathrm{m}^{2}\right.$, measured data).

The WHO suggested a median BMI of $21-23 \mathrm{~kg} / \mathrm{m}^{2}$ as an optimum for a population to reduce the risk of chronic diseases and obesity, where a median BMI of $21 \mathrm{~kg} / \mathrm{m}^{2}$ is considered as being more beneficial for affluent societies with a more sedentary lifestyle and a BMI of $23 \mathrm{~kg} / \mathrm{m}^{2}$ for developing countries [WHO, 2000, 2003]. Eurodiet [2000] recommends a mean BMI of $21-22 \mathrm{~kg} / \mathrm{m}^{2}$. The range was exceeded by every country in both men and women; only Austrian and Polish women (median BMI 22.7 and $22.8 \mathrm{~kg} / \mathrm{m}^{2}$ ) - both derived from selfreported data on body height and body weight - kept in the range of the WHO recommendation.

Table 8.5 shows that the BMIs in the defined European regions did not differ substantially, neither for self-reported nor for measured data. 
Table 8.3. Study populations for assessment of overweight and obesity in elderly (65+ years) in the participating countries. Self-reported: $n=27,874$ from 13 countries; measured: $n=25,805$ from 10 countries

\begin{tabular}{|c|c|c|c|c|}
\hline Country & Survey name & Female & Male & Age, years \\
\hline \multicolumn{5}{|l|}{ Self-reported ${ }^{1}$} \\
\hline Austria & Austrian Study on Nutritional Status - OESES.sen07 & 484 & 204 & $65+$ \\
\hline Belgium & Food Consumption Survey, Belgium, 2004 & 1,623 & 1,626 & $65+$ \\
\hline Denmark & Danish National Survey on Dietary Habits and Physical Activity & 162 & 164 & $65+$ \\
\hline \multirow[t]{3}{*}{ Estonia } & Estonian Health Interview Survey, 2006 & 3,114 & 2,872 & $65+$ \\
\hline & Health Behavior among Estonian Adult Population, 2004 & 1,633 & 1,203 & $65+$ \\
\hline & Health Behavior among Estonian Adult Population, 2006 & 1,603 & 1,030 & $65+$ \\
\hline Germany $^{1}$ & National Telephone Health Survey (GSTeL03), 2004 & 4,302 & 4,016 & $65+$ \\
\hline Ireland & Survey of Lifestyle, Attitudes and Nutrition, 2007 & 786 & 891 & $65+$ \\
\hline Italy & Health-for-All database (ISTAT, updated in 2009) & n.a. & n.a. & $65+$ \\
\hline \multirow[t]{3}{*}{ Lithuania } & $\begin{array}{l}\text { Statistics Lithuania. Health survey results of Lithuanian } \\
\text { population in } 2005\end{array}$ & n.a. & n.a. & $65-74$ \\
\hline & $\begin{array}{l}\text { Statistics Lithuania. Health survey results of Lithuanian } \\
\text { population in } 2005\end{array}$ & n.a. & n.a. & $75-84$ \\
\hline & $\begin{array}{l}\text { Statistics Lithuania. Health survey results of Lithuanian } \\
\text { population in } 2005\end{array}$ & n.a. & n.a. & $85+$ \\
\hline Norway & Norkost 1997 & n.a. & n.a. & $65+$ \\
\hline Poland & Low income & 200 & 40 & $65+$ \\
\hline Sweden & $\begin{array}{l}\text { National public health survey. Health on equal terms? } 2007 \\
\text { National Institute of Public Health, Sweden }\end{array}$ & 700 & 597 & $65+$ \\
\hline \multirow[t]{2}{*}{ The Netherlands } & CBS Statline, 2007 & 105 & 98 & $65+$ \\
\hline & DNFCS-3, 1997/98 & 236 & 185 & $65+$ \\
\hline \multirow[t]{2}{*}{ UK } & Health Surveys for England, 2006 & n.a. & n.a. & $65-74$ \\
\hline & Health Surveys for England, 2006 & n.a. & n.a. & $75+$ \\
\hline \multicolumn{5}{|l|}{ Measured $^{2}$} \\
\hline Austria & Austrian Study on Nutritional Status - OESES.sen07 & 484 & 204 & $65+$ \\
\hline Cyprus & CyDA 1st Epidemiological Study & 256 & 187 & $65+$ \\
\hline Finland & FINRISK, 2007. Lääkärilehti, 2008 & 3,979 & 3,984 & $65+$ \\
\hline France & French Nutrition and Health Survey (ENNS), 2006-2007 & 2,273 & 1,604 & $65-74$ \\
\hline Germany & German Nutrition Survey II, 2005-2007 & 1,435 & 1,377 & $65+$ \\
\hline Greece & EPIC study, 1994-1999 & 3,600 & 2,508 & $65+$ \\
\hline
\end{tabular}


Table 8.3. Continued

\begin{tabular}{lllll}
\hline Country & Survey name & Female & Male & Age, years \\
\hline Ireland & Survey of Lifestyle, Attitudes and Nutrition, 2007 & 220 & 179 & $65+$ \\
\hline Poland & $\begin{array}{l}\text { Household Food Consumption and Anthropometric Survey, } \\
2000\end{array}$ & 1,469 & 1,346 & $65+$ \\
\hline Portugal & $\begin{array}{l}\text { Data collected for PhD diss. thesis in Faculty of Nutrition and } \\
\text { Food Sciences, Oporto University }\end{array}$ & 192 & 194 & $65+$ \\
\hline Spain & Catalan Nutrition Survey (ENCAT), 2002-2003 & 161 & 153 & $65+$ \\
\hline $\begin{array}{l}\text { 'Body weight and body height reported by the participants. } \\
\text { 2Body weight and body height measured by researchers. }\end{array}$ & & & \\
\hline
\end{tabular}

Fig. 8.2 shows a remarkable prevalence of overweight and obesity in adults. As was the BMI, the prevalence of overweight and obesity was generally higher in men than in women. The highest prevalence for overweight and obesity was seen in Greek women (73\%) and Cyprian men (83\%). The lowest prevalence was found for Norwegian and Austrian women (31\%) and for men from Sweden $(38 \%)$.

The difference in prevalence of overweight and obesity between countries that provided measured data and countries that provided self-reported data was considerable. Whereas the maximum prevalence of overweight and obesity in men was $82 \%$ (minimum 51\%) from measured data it was 58\% (minimum 40\%) from self-reported data; in women it was $61 \%$ (minimum $40 \%$ ) for measured data and $49 \%$ (minimum $25 \%$ ) for self-reported data. Thus, interpretation of data must be undertaken carefully. No considerable differences in the prevalence of overweight and obesity between the regions could be observed.

A comparison of prevalence of overweight and obesity between data from the European Nutrition and Health Report 2004 and 2009 was possible for 10 countries. For women and for men, no big change in the prevalence could be observed (table 8.6).

\section{BMI, Overweight and Obesity in Elderly (65+ Years)}

The mean BMI of elderly people as well as the prevalence of overweight and obesity was higher than in the younger adults. Table 8.7 shows the mean BMI of the elderly of European countries. The lowest mean BMI was seen in Danish women $\left(24.7 \mathrm{~kg} / \mathrm{m}^{2}\right)$, the highest in Polish men $\left(28.5 \mathrm{~kg} / \mathrm{m}^{2}\right)$.

During the last years it has been shown that for the elderly population a higher BMI than for younger adults is associated with positive health outcomes. Therefore the National Research Council of the USA suggests a range of $24-29 \mathrm{~kg} / \mathrm{m}^{2}$ for over 
Table 8.4. BMI self-reported and measured (median, mean, SD) in European 19- to 64-year-old men and women

\begin{tabular}{|c|c|c|c|c|c|c|c|}
\hline \multirow[t]{2}{*}{ Country } & \multirow[t]{2}{*}{ Age, years } & \multicolumn{3}{|l|}{ Women } & \multicolumn{3}{|l|}{ Men } \\
\hline & & median & mean & SD & median & mean & SD \\
\hline
\end{tabular}

Self-reported

\begin{tabular}{|c|c|c|c|c|c|c|c|}
\hline Austria & 19-64 & 22.7 & 23.8 & 4.5 & 25.3 & 25.8 & 3.7 \\
\hline Belgium & 19-63 & 23.1 & 24.2 & 4.6 & 25.3 & 25.6 & 4.0 \\
\hline Denmark & 19-64 & 23.2 & 24.1 & 4.3 & 24.9 & 25.5 & 3.5 \\
\hline Estonia & 19-63 & 24.2 & 25.3 & 5.5 & 25.6 & 26.3 & 4.5 \\
\hline \multirow[t]{4}{*}{ Hungary } & $\begin{array}{l}\text { Mean of age } \\
\text { groups }\end{array}$ & n.a. & 25.3 & n.a. & n.a. & 27.6 & n.a. \\
\hline & $18-34$ & n.a. & 22.9 & 4.5 & n.a. & 24.7 & 3.8 \\
\hline & $35-59$ & n.a. & 26.1 & 4.6 & n.a. & 26.8 & 3.9 \\
\hline & $60+$ & n.a. & 27.0 & 4.1 & n.a. & 27.6 & 3.9 \\
\hline \multirow[t]{3}{*}{ Ireland } & $\begin{array}{l}\text { Mean of age } \\
\text { groups }\end{array}$ & n.a. & 25.2 & n.a. & n.a. & 26.5 & n.a. \\
\hline & $18-44$ & 23.1 & 24.2 & 4.5 & 25.0 & 25.5 & 4.2 \\
\hline & $45-64$ & 25.4 & 26.2 & 4.8 & 27.1 & 27.4 & 3.7 \\
\hline Lithuania & $20-64$ & 24.9 & 25.7 & 4.9 & 25.8 & 26.6 & 4.5 \\
\hline Norway & 19-63 & 23.4 & 23.9 & 3.9 & 24.8 & 25.2 & 3.3 \\
\hline Poland & $19-63$ & 22.8 & 23.8 & 4.3 & 24.9 & 25.7 & 2.7 \\
\hline Portugal & $20-64$ & 24.5 & 25.3 & 4.8 & 25.6 & 26.0 & 3.8 \\
\hline Sweden & 19-64 & 23.8 & 24.7 & 4.5 & 25.5 & 26.2 & 3.9 \\
\hline \multirow[t]{2}{*}{ The Netherlands } & 19-64 & 23.9 & 24.8 & 4.5 & 24.7 & 24.9 & 3.4 \\
\hline & & \multicolumn{3}{|c|}{$\min .22 .9, \max .27 .0$} & \multicolumn{3}{|c|}{$\min .24 .9, \max .27 .6$} \\
\hline \multicolumn{8}{|l|}{ Measured } \\
\hline Cyprus & $19-64$ & 26.8 & $26.8^{1}$ & n.a. & 28.6 & $28.6^{1}$ & \\
\hline Czech Republic & $19-64$ & 26.5 & 27.4 & 5.7 & 27.6 & 28.6 & 4.4 \\
\hline Finland & $25-64$ & & 26.9 & 5.4 & & 27.4 & 4.2 \\
\hline France & 19-64 & 23.8 & 25.1 & 0.2 & 25.6 & 26.0 & 0.2 \\
\hline Germany & 19-64 & 24.3 & 25.6 & 5.1 & 26.2 & 26.7 & 4.7 \\
\hline Greece & 19-64 & 28.0 & 28.6 & 5.3 & 27.9 & 28.2 & 3.8 \\
\hline Ireland & 19-64 & n.a. & 25.8 & 4.8 & n.a. & 26.9 & 4.0 \\
\hline Latvia & 19-64 & n.a. & 25.8 & 4.9 & n.a. & 25.5 & 3.7 \\
\hline
\end{tabular}


Table 8.4. Continued

\begin{tabular}{|c|c|c|c|c|c|c|c|}
\hline \multirow[t]{2}{*}{ Country } & \multirow[t]{2}{*}{ Age, years } & \multicolumn{3}{|l|}{ Women } & \multicolumn{3}{|l|}{ Men } \\
\hline & & median & mean & $\mathrm{SD}$ & median & mean & SD \\
\hline Lithuania & $19-64$ & 24.6 & 25.5 & 5.0 & 25.6 & 26.0 & 3.7 \\
\hline Poland & $19-64$ & 24.3 & 25.3 & 5.0 & 25.5 & 26.1 & 4.0 \\
\hline Portugal & $19-64$ & 24.7 & 25.2 & 4.6 & 25.7 & 26.2 & 3.7 \\
\hline Romania & $19-64$ & 24.8 & 25.2 & 4.3 & 26.2 & 26.8 & 5.0 \\
\hline Spain & $19-64$ & 24.0 & 24.8 & 4.5 & 26.0 & 26.2 & 3.8 \\
\hline \multirow[t]{7}{*}{ UK } & $\begin{array}{l}\text { Mean of age } \\
\text { groups }\end{array}$ & n.a. & 26.4 & n.a. & n.a. & 27.1 & n.a. \\
\hline & $16-24$ & n.a. & 24.0 & 6.0 & n.a. & 24.1 & 6.3 \\
\hline & $25-34$ & n.a. & 25.9 & 5.7 & n.a. & 26.7 & 5.4 \\
\hline & $35-44$ & n.a. & 26.8 & 5.5 & n.a. & 27.8 & 5.1 \\
\hline & $45-54$ & n.a. & 27.6 & 5.3 & n.a. & 28.0 & 4.6 \\
\hline & $55-64$ & n.a. & 28.0 & 4.8 & n.a. & 28.6 & 4.5 \\
\hline & & \multicolumn{3}{|c|}{$\min .24 .8, \max .28 .6$} & \multicolumn{3}{|c|}{$\min .25 .5, \max .28 .6$} \\
\hline
\end{tabular}

Table 8.5. Maximum and minimum values of the mean BMI in adults aged 19-64 years the European regions by sex

\begin{tabular}{|c|c|c|c|c|c|}
\hline & & \multicolumn{2}{|c|}{ Self-reported } & \multicolumn{2}{|l|}{ Measured } \\
\hline & & minimum & maximum & minimum & maximum \\
\hline \multirow[t]{2}{*}{ Central and East } & Female & 23.8 & 25.3 & 25.2 & 27.4 \\
\hline & Male & 25.7 & 27.6 & 26.1 & 28.6 \\
\hline \multirow[t]{2}{*}{ North } & Female & 23.9 & 25.7 & 25.5 & 26.9 \\
\hline & Male & 25.1 & 26.6 & 25.5 & 27.4 \\
\hline \multirow[t]{2}{*}{ South } & Female & 23.3 & 25.3 & 24.8 & 28.6 \\
\hline & Male & 25.4 & 26.0 & 26.2 & 28.2 \\
\hline \multirow[t]{2}{*}{ West } & Female & 24.2 & 25.2 & 25.1 & 26.4 \\
\hline & Male & 24.9 & 26.5 & 26.0 & 27.1 \\
\hline
\end{tabular}




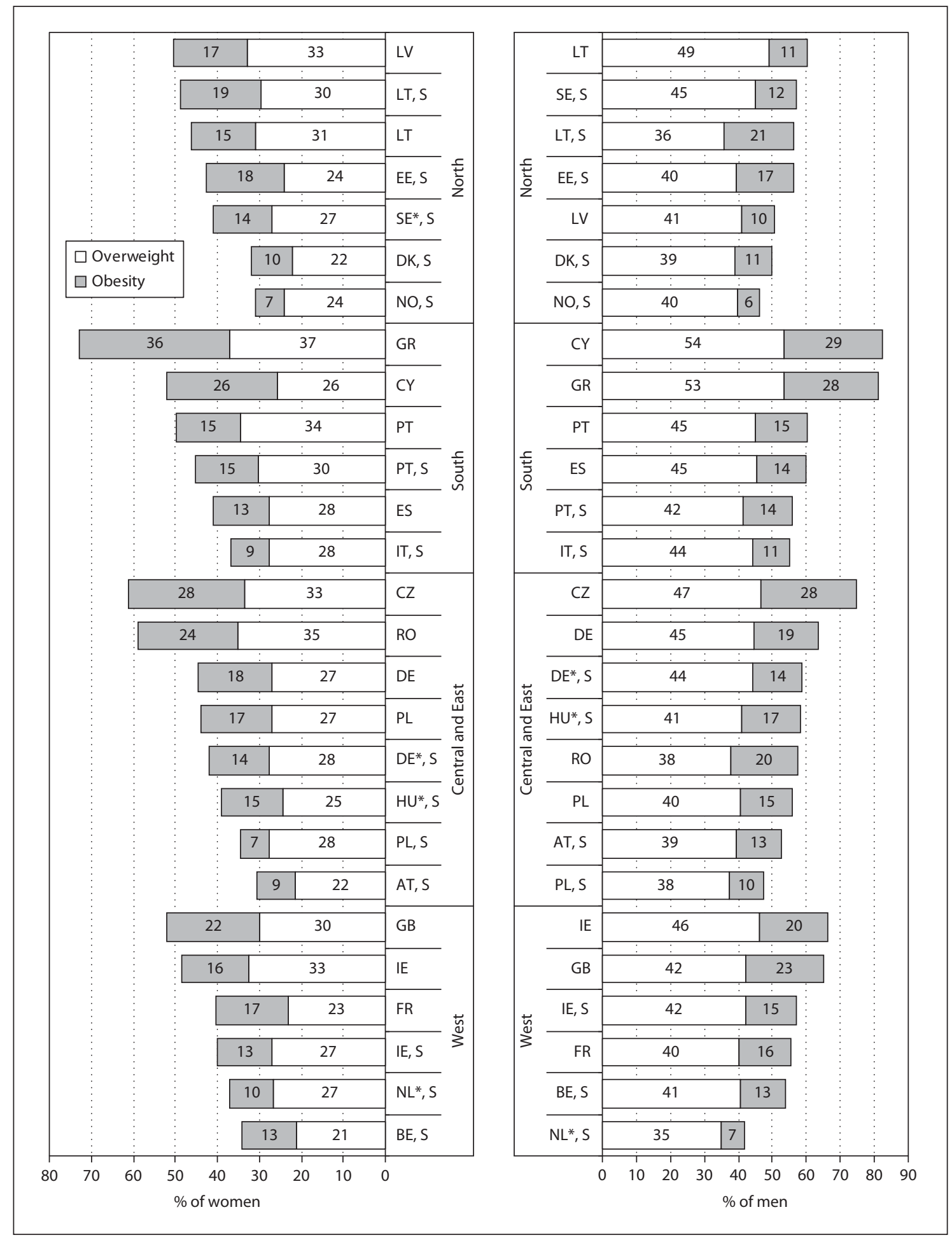

Fig. 8.2. Overweight and obesity in European 19- to 64-year-old adults ordered by region. S = BMI calculated from self-reported height and weight. *Estimated from mean values for different age groups. 
Table 8.6. Comparison of prevalence of overweight and obesity in men and women aged 19-64 years in 2004 and 2009

\begin{tabular}{|c|c|c|c|c|c|}
\hline 2004 & & & 2009 & & \\
\hline BMI & overweight \% & obesity \% & BMI & overweight \% & obesity \% \\
\hline
\end{tabular}

\section{Men}

\begin{tabular}{lllllll}
\hline UK & $\mathrm{m}$ & 41 & 25 & $\mathrm{~s}$ & 46 & 27 \\
\hline Spain & $\mathrm{m}$ & 45 & 13 & $\mathrm{~m}$ & 45 & 14 \\
\hline Portugal & $\mathrm{m}$ & 41 & 13 & $\mathrm{~m}$ & 45 & 15 \\
\hline Italy & $\mathrm{s}$ & 42 & 9 & $\mathrm{~s}$ & 44 & 11 \\
\hline Hungary & $\mathrm{m}$ & 42 & 21 & $\mathrm{~s}$ & 42 & 20 \\
\hline $\begin{array}{l}\text { Germany (mean West/ } \\
\text { East) }\end{array}$ & $\mathrm{m}$ & 47 & 20 & $\mathrm{~m}$ & 45 & 19 \\
\hline Finland & $\mathrm{n} . \mathrm{i}$. & 49 & 19 & $\mathrm{~m}$ & 48 & 22 \\
\hline France & $\mathrm{m}$ & 47 & 10 & $\mathrm{~m}$ & 40 & 16 \\
\hline Belgium & $\mathrm{s}$ & 40 & 10 & $\mathrm{~s}$ & 41 & 13 \\
\hline Austria & $\mathrm{s}$ & 35 & 6 & $\mathrm{~s}$ & 39 & 13
\end{tabular}

Women

\begin{tabular}{lllllll}
\hline UK & $\mathrm{m}$ & 33 & 20 & $\mathrm{~s}$ & 33 & 25 \\
\hline Spain & $\mathrm{m}$ & 32 & 16 & $\mathrm{~m}$ & 28 & 13 \\
\hline Portugal & $\mathrm{m}$ & 31 & 15 & $\mathrm{~m}$ & 34 & 15 \\
\hline Italy & $\mathrm{s}$ & 26 & 9 & $\mathrm{~s}$ & 28 & 10 \\
\hline Hungary & $\mathrm{m}$ & 28 & 21 & $\mathrm{~s}$ & 30 & 17 \\
\hline Germany (mean West/ & $\mathrm{m}$ & 32 & 23 & $\mathrm{~m}$ & 27 & 18 \\
East) & $\mathrm{n} . \mathrm{i}$. & 33 & 18 & $\mathrm{~m}$ & 33 & 23 \\
\hline Finland & $\mathrm{m}$ & 21 & 7 & $\mathrm{~m}$ & 23 & 17 \\
\hline France & $\mathrm{s}$ & 26 & 12 & $\mathrm{~s}$ & 21 & 13 \\
\hline Belgium & $\mathrm{s}$ & 20 & 6 & $\mathrm{~s}$ & 22 & 9
\end{tabular}

$\mathrm{m}=\mathrm{BMI}$ calculated from measured body height and weight; $\mathrm{s}=\mathrm{BMI}$ calculated from self-reported body height and weight; $n$.i. = method used not indicated. 
Table 8.7. BMI self-reported and measured (median, mean, SD) in European men and women from 65+ years

\begin{tabular}{|c|c|c|c|c|c|c|c|}
\hline \multirow[t]{2}{*}{ Country } & \multirow[t]{2}{*}{ Age years } & \multicolumn{3}{|l|}{ Women } & \multicolumn{3}{|l|}{ Men } \\
\hline & & median & mean & SD & median & mean & SD \\
\hline \multicolumn{8}{|l|}{ Self-reported } \\
\hline Austria & $65+$ & 26.0 & 26.7 & 4.9 & 27.6 & 27.8 & 3.6 \\
\hline Belgium & $65+$ & 25.3 & 25.7 & 4.4 & 25.7 & 25.9 & 3.5 \\
\hline Denmark & $65+$ & 24.5 & 24.7 & 4.4 & 25.5 & 26.0 & 3.2 \\
\hline Estonia & $65+$ & 27.0 & 27.6 & 5.0 & 25.8 & 26.3 & 3.9 \\
\hline Ireland & $65+$ & 24.8 & 25.2 & 4.5 & 26.0 & 26.4 & 3.9 \\
\hline Lithuania & $65+$ & n.a. & 26.4 & n.a. & n.a. & 25.9 & n.a. \\
\hline Norway & $65+$ & 25.0 & 25.7 & 4.7 & 24.6 & 25.1 & 2.8 \\
\hline Poland & $65+$ & 25.0 & 25.7 & 3.9 & 27.9 & 28.5 & 4.6 \\
\hline Portugal & $65+$ & 26.1 & 26.6 & 4.9 & 26.3 & 26.0 & 3.9 \\
\hline Sweden & $65+$ & 25.2 & 25.6 & 3.8 & 26.2 & 26.3 & 3.0 \\
\hline The Netherlands & $65+$ & 26.0 & 26.8 & 4.6 & 25.2 & 25.4 & 2.9 \\
\hline \multirow[t]{2}{*}{ UK } & $65+$ & n.a. & 28.1 & n.a. & n.a. & 27.7 & n.a. \\
\hline & & \multicolumn{3}{|c|}{$\min .24 .7, \max .28 .1$} & \multicolumn{3}{|c|}{$\min .25 .1, \max .28 .5$} \\
\hline \multicolumn{8}{|l|}{ Measured } \\
\hline Austria & $65+$ & 28.0 & 28.7 & 4.9 & 29.1 & 29.6 & 3.9 \\
\hline Cyprus & $65+$ & 26.8 & n.a. & n.a. & 28.6 & n.a. & n.a. \\
\hline Finland & $65+$ & n.a. & 28.5 & 5.0 & n.a. & 28.0 & 2.8 \\
\hline France & $65-74$ & 25.4 & 26.4 & 0.4 & 28.0 & 28.0 & 0.4 \\
\hline Germany & $65+$ & 27.8 & 28.3 & 5.0 & 28.1 & 28.4 & 3.7 \\
\hline Greece & $65+$ & 30.3 & 30.6 & 4.9 & 28.1 & 28.2 & 4.0 \\
\hline Ireland & $65+$ & 28.0 & 28.1 & 5.0 & 27.5 & 27.8 & 4.1 \\
\hline Poland & $65+$ & 28.0 & 28.1 & 5.0 & 26.3 & 26.3 & 3.9 \\
\hline Portugal & $65+$ & 27.7 & 27.8 & 4.5 & 27.4 & 27.2 & 3.8 \\
\hline \multirow[t]{2}{*}{ Spain } & $65+$ & 28.6 & 28.4 & 4.3 & 27.6 & 27.6 & 3.6 \\
\hline & & \multicolumn{3}{|c|}{$\min .26 .4, \max .30 .6$} & \multicolumn{3}{|c|}{$\min .26 .3, \max .29 .6$} \\
\hline
\end{tabular}




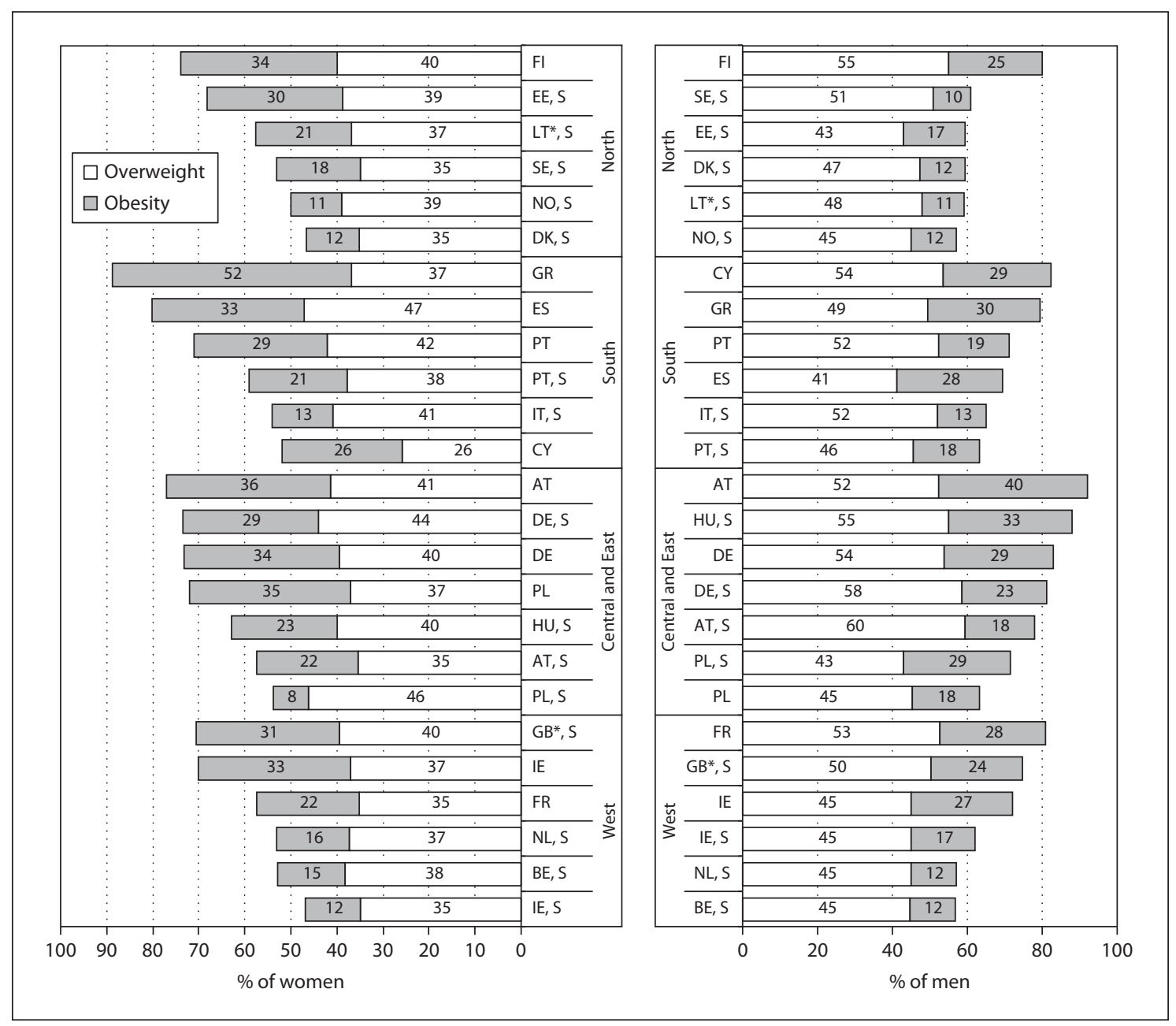

Fig. 8.3. Overweight and obesity in European elderly (65+ years) ordered by region. $S=B M I$ calculated from self-reported height and weight. *Estimated from mean values for different age groups.

65-year-olds as normal body weight [NRC, 1989]. Applying these (individually based) recommendations on the mean of the countries, it can be seen that the mean BMIs of all countries were within this range except for Greek women $\left(30.6 \mathrm{~kg} / \mathrm{m}^{2}\right)$.

The lowest prevalence for overweight and obesity was found in elderly women from Denmark, Italy and Ireland (47\%), for Norwegian and Belgian men (48\%; the highest prevalence was seen in Greek women (89\%) and Austrian men (92\%) (fig. 8.3). No big differences between the mean prevalence of overweight and obesity could be observed between the regions. 


\subsection{Blood Lipids $^{1}$}

In tables 8.8-8.9, the blood lipid status of the different European countries is shown. These data were available from 8 European countries for adults of both sexes (1964 years of age) and from 6 European countries for elderly women and men ( $\geq 65$ years of age). A detailed description of the surveys conducted in the individual countries is given in chapter 7, 'Energy and Nutrient Intake in the European Union', as well as in chapter 11, 'National Reports'. The guidelines of the European Society of Cardiology (ESC) were applied as reference values [Graham et al., 2007].

Except for 19- to 34-year-old women and men from the UK and Greek adult women, the average total cholesterol levels were in all European countries at or above the reference value of $5.0 \mathrm{mmol} / \mathrm{l}$ (table 8.8 ). For elderly women and men ( $\geq 65$ years), the average total cholesterol levels were also equal or above the reference value across Europe (table 8.9).

The average levels of LDL-Cholesterol for both sexes in all European countries were equal or above the reference value of $3.0 \mathrm{mmol} / \mathrm{l}$; the reported values for adult men were slightly higher than for adult women. The average levels of HDL-Cholesterol of all European countries were clearly above the reference value of at least $1.2 \mathrm{mmol} / \mathrm{l}$ for women and $1.0 \mathrm{mmol} / \mathrm{l}$ for men (tables 8.8, 8.9). Except for Romanian adults and adult men from Lithuania and Portugal, levels of triacylglycerides were below the upper level of $1.7 \mathrm{mmol} / \mathrm{l}$ across Europe. The atherogenic quotient (calculated from average values of each country) was higher in men than in women but values for both sexes were within the normal range (3-5 $\mathrm{mmol} / \mathrm{l})$.

\subsection{Mortality/Morbidity}

The data about mortality of the different European countries originate from the European Health-for-All database of the WHO [WHO, 2009a]. Within this database, data about mortality rates were available from 10 European countries from 2007. Data are presented as age standardized death rate per 100,000 alive and represents what the crude rate would have been if the population had the same age distribution as the standard European population (fig. 8.4).

The highest total mortality rate in women was found in Latvia (777 deaths/100,000 women alive), followed by Romania and Lithuania (764 and 731 deaths/100,000 women alive, respectively) (fig. 8.4). The lowest mortality rates in women were observed in Finland and Austria (445 and 448 deaths/100,000 women alive). In men, the highest mortality rate was in Lithuania with 1,621 deaths/100,000 men alive, followed by Latvia and Romania (1,565 and 1,242 deaths/100,000 men alive). The lowest

${ }_{1}$ Chapters 8.2, 8.3, 8.4 and 8.5 by Krems C, Strassburg A: Max Rubner-Institut, Federal Research Institute of Nutrition and Food, Karlsruhe, Germany (carolin.krems@mri.bund.de). 
Table 8.8. Blood lipids in serum/plasma in different European countries (mmol/l), women and men 19-64 years of age

\begin{tabular}{|c|c|c|c|c|c|c|c|}
\hline Country & Survey name & $\begin{array}{l}\text { Survey } \\
\text { year }\end{array}$ & $\begin{array}{l}\text { Total cholesterol } \\
\text { mean } \pm S D\end{array}$ & $\begin{array}{l}\text { LDL chol. } \\
\text { mean } \pm S D\end{array}$ & $\begin{array}{l}\text { HDL chol. } \\
\text { mean } \pm S D\end{array}$ & $\begin{array}{l}\text { Trigly- } \\
\text { cerides } \\
\text { mean } \pm S D\end{array}$ & $\begin{array}{l}\text { Total chol./ } \\
\text { HDL chol. }{ }^{5}\end{array}$ \\
\hline
\end{tabular}

\section{Women}

\begin{tabular}{|c|c|c|c|c|c|c|c|}
\hline Finland $^{1}$ & FINRISK Study & 2007 & $5.2 \pm 1.0$ & & & & \\
\hline Greece & ATTICA Study & 2001-2002 & $4.9 \pm 1.1$ & $3.1 \pm 0.9$ & $1.4 \pm 0.4$ & $1.2 \pm 0.6$ & 3.5 \\
\hline Lithuania & $\begin{array}{l}\text { Countrywide Integrated } \\
\text { Non-Communicable } \\
\text { Diseases Intervention } \\
\text { Survey }\end{array}$ & 2007 & $5.2 \pm 1.1$ & $3.0 \pm 1.0$ & $1.4 \pm 0.4$ & $1.5 \pm 0.7$ & 3.7 \\
\hline Portugal & $\begin{array}{l}\text { Epidemiological study to } \\
\text { characterize the lipid } \\
\text { profile of the Portuguese } \\
\text { population }\end{array}$ & 2001 & 5.5 & 3.6 & 1.5 & 1.2 & 3.7 \\
\hline Spain & Catalan Nutrition Survey & $2002-2003$ & $5.0 \pm 1.3$ & $3.1 \pm 1.1$ & $1.5 \pm 0.4$ & $0.9 \pm 0.5$ & 3.3 \\
\hline \multirow[t]{3}{*}{$\mathrm{UK}^{3}$} & $\begin{array}{l}\text { Low-income diet and } \\
\text { health survey }\end{array}$ & $\begin{array}{l}\text { 2003-2005 } \\
\text { a) }\end{array}$ & $4.9 \pm 1.0$ & & $1.4 \pm 0.3$ & & 3.5 \\
\hline & & b) & $5.4 \pm 1.0$ & & $1.5 \pm 0.3$ & & 3.6 \\
\hline & & c) & $6.2 \pm 1.4$ & & $1.5 \pm 0.4$ & & 4.1 \\
\hline $\begin{array}{l}\text { Reference } \\
\text { value }^{4}\end{array}$ & & & $<5.0$ & $<3.0$ & $>1.2$ & $<1.7$ & \\
\hline
\end{tabular}

\section{Men}

\begin{tabular}{|c|c|c|c|c|c|c|c|}
\hline Finland $^{1}$ & FINRISK Study & 2007 & $5.3 \pm 1.0$ & & & & \\
\hline France & $\begin{array}{l}\text { French Nutrition and } \\
\text { Health Survey }\end{array}$ & 2006-2007 & $5.4 \pm 0.7$ & $3.4 \pm 0.1$ & $1.4 \pm 0.0$ & $1.4 \pm 0.9$ & 3.9 \\
\hline Greece & ATTICA Study & 2001-2002 & $5.0 \pm 1.1$ & $3.2 \pm 1.0$ & $1.2 \pm 0.4$ & $1.6 \pm 0.6$ & 4.2 \\
\hline Lithuania $^{1}$ & $\begin{array}{l}\text { Countrywide Integrated } \\
\text { Non-communicable } \\
\text { Diseases Intervention } \\
\text { Survey }\end{array}$ & 2007 & $5.2 \pm 1.1$ & $3.2 \pm 1.0$ & $1.3 \pm 0.4$ & $1.7 \pm 0.9$ & 4.0 \\
\hline
\end{tabular}


Table 8.8. Continued

\begin{tabular}{|c|c|c|c|c|c|c|c|}
\hline Country & Survey name & $\begin{array}{l}\text { Survey } \\
\text { year }\end{array}$ & $\begin{array}{l}\text { Total cholesterol } \\
\text { mean } \pm \text { SD }\end{array}$ & $\begin{array}{l}\text { LDL chol. } \\
\text { mean } \pm \text { SD }\end{array}$ & $\begin{array}{l}\mathrm{HDL} \text { chol. } \\
\text { mean } \pm \mathrm{SD}\end{array}$ & $\begin{array}{l}\text { Trigly- } \\
\text { cerides } \\
\text { mean } \pm S D\end{array}$ & $\begin{array}{l}\text { Total chol./ } \\
\text { HDL chol. }\end{array}$ \\
\hline Portugal & $\begin{array}{l}\text { Epidemiological study to } \\
\text { characterize the lipid } \\
\text { profile of the Portuguese } \\
\text { population }\end{array}$ & 2001 & 5.5 & 3.6 & 1.2 & 1.9 & 4.6 \\
\hline Romania $^{2}$ & $\begin{array}{l}\text { Nutritional status in adult } \\
\text { population in relation to } \\
\text { the food intake }\end{array}$ & 2002 & $5.0 \pm 1.4$ & & $1.4 \pm 0.3$ & $1.7 \pm 1.2$ & 3.6 \\
\hline Spain & Catalan Nutrition Survey & $2002-2003$ & $5.0 \pm 1.0$ & $3.3 \pm 0.8$ & $1.2 \pm 0.3$ & $1.2 \pm 1.0$ & 4.2 \\
\hline \multirow[t]{3}{*}{$\mathrm{UK}^{3}$} & $\begin{array}{l}\text { Low-income diet and } \\
\text { health survey }\end{array}$ & $\begin{array}{l}\text { 2003-2005 } \\
\text { a) }\end{array}$ & $4.9 \pm 1.0$ & & $1.4 \pm 0.3$ & & 3.5 \\
\hline & & b) & $5.9 \pm 1.5$ & & $1.3 \pm 0.4$ & & 4.5 \\
\hline & & c) & $5.7 \pm 1.2$ & & $1.3 \pm 0.4$ & & 4.4 \\
\hline $\begin{array}{l}\text { Reference } \\
\text { value }^{4}\end{array}$ & & & $<5.0$ & $<3.0$ & $>1.0$ & $<1.7$ & \\
\hline \multicolumn{8}{|c|}{$\begin{array}{l}{ }^{1} \text { Age: } 25-64 \text { years. } \\
{ }^{2} \text { Age: } 55-64 \text { years. } \\
{ }^{3} \text { Age: a) } 19-34 \text { years, b) } 35-49 \text { years, c) } 50-64 \text { years. } \\
{ }^{4} \text { Graham et al. [2007]. } \\
{ }^{5} \text { Calculated from average total cholesterol and } \mathrm{HDL}\end{array}$} \\
\hline
\end{tabular}

mortality rates in men were observed for The Netherlands and the UK (708 and 712 deaths/100,000 men alive). In all European countries, men had a higher mortality rate than women.

Cardiovascular diseases (CVD) were the leading cause of death across the European countries [WHO, 2009a]. The highest mortality rates from CVD were found for women and men from Latvia, Lithuania and Romania, respectively (fig. 8.4). The lowest rates of deaths from CVD were observed for women and men from The Netherlands (134 and 210 deaths/100,000 subjects alive, respectively). In all European countries, men showed higher mortality rates from CVD than women. In particular, theses differences were very large in Latvia, Lithuania and Romania.

The second most frequent cause of death across Europe was malignant neoplasms (MN) [WHO, 2009a]. In women, the highest mortality rate from MN was found in the Czech Republic, followed by UK and The Netherlands with only minor differences (155, 154 and 151 deaths/100,000 women alive, respectively) (fig. 8.4). The 
Table 8.9. Blood lipids in serum/plasma in different European countries $(\mathrm{mmol} / \mathrm{L})$, women and men $65+$ years of age

\begin{tabular}{|c|c|c|c|c|c|c|c|}
\hline Country & Survey name & $\begin{array}{l}\text { Survey } \\
\text { year }\end{array}$ & $\begin{array}{l}\text { Total cholesterol } \\
\text { mean } \pm S D\end{array}$ & $\begin{array}{l}\text { LDL-chol. } \\
\text { mean } \pm S D\end{array}$ & $\begin{array}{l}\mathrm{HDL}-\mathrm{chol} \\
\text { mean } \pm \mathrm{SD}\end{array}$ & $\begin{array}{l}\text { Trigly- } \\
\text { cerides } \\
\text { mean } \pm S D\end{array}$ & $\begin{array}{l}\text { Total chol./ } \\
\text { HDL-chol. }^{2}\end{array}$ \\
\hline \multicolumn{8}{|l|}{ Women } \\
\hline Austria & $\begin{array}{l}\text { Nutritional Status in } \\
\text { Elderly }\end{array}$ & 2007 & $5.7 \pm 0.8$ & $3.6 \pm 0.7$ & $1.6 \pm 0.4$ & $1.2 \pm 0.6$ & 3.6 \\
\hline Finland & FINRISK Study & 2007 & $5.5 \pm 1.0$ & & 1.6 & & \\
\hline France & $\begin{array}{l}\text { French Nutrition and } \\
\text { Health Survey }\end{array}$ & $2006-2007$ & $5.9 \pm 0.1$ & $3.6 \pm 0.1$ & $1.7 \pm 0.0$ & $1.2 \pm 0.1$ & 3.5 \\
\hline Romania & $\begin{array}{l}\text { Nutritional status in } \\
\text { adult population in } \\
\text { relation to the food } \\
\text { intake }\end{array}$ & 2002 & $5.1 \pm 1.2$ & & & $1.6 \pm 1.1$ & \\
\hline Spain & Catalan Nutrition Survey & $2002-2003$ & $5.8 \pm 1.0$ & $3.7 \pm 0.9$ & $1.4 \pm 0.4$ & $1.3 \pm 0.7$ & 4.1 \\
\hline UK & $\begin{array}{l}\text { Low-income diet and } \\
\text { health survey }\end{array}$ & $2003-2005$ & $5.9 \pm 1.4$ & & $1.6 \pm 0.4$ & & 3.7 \\
\hline \multicolumn{8}{|l|}{ Men } \\
\hline Austria & $\begin{array}{l}\text { Nutritional Status in } \\
\text { Elderly }\end{array}$ & 2007 & $5.4 \pm 0.9$ & $3.4 \pm 0.8$ & $1.4 \pm 0.3$ & $1.4 \pm 0.7$ & 3.9 \\
\hline Finland & FINRISK Study & 2007 & $5.0 \pm 1.0$ & & 1.3 & & \\
\hline France & $\begin{array}{l}\text { French Nutrition and } \\
\text { Health Survey }\end{array}$ & $2006-2007$ & $5.2 \pm 0.2$ & $3.2 \pm 0.1$ & $1.3 \pm 0.1$ & $1.5 \pm 0.1$ & 4.0 \\
\hline Romania & $\begin{array}{l}\text { Nutritional status in } \\
\text { adult population in } \\
\text { relation to the food } \\
\text { intake }\end{array}$ & 2002 & $5.0 \pm 1.2$ & & & $1.6 \pm 1.0$ & \\
\hline Spain & $\begin{array}{l}\text { Catalan Nutrition and } \\
\text { Health Survey }\end{array}$ & $2002-2003$ & $5.2 \pm 1.0$ & $3.3 \pm 0.7$ & $1.3 \pm 0.4$ & $1.2 \pm 0.7$ & 3.9 \\
\hline UK & $\begin{array}{l}\text { Low-income diet and } \\
\text { health survey }\end{array}$ & $2003-2005$ & $5.2 \pm 1.2$ & & $1.3 \pm 0.4$ & & 4.0 \\
\hline $\begin{array}{l}\text { Reference } \\
\text { value }^{1}\end{array}$ & & & $<5.0$ & $<3.0$ & $\begin{array}{l}f>1.2 \\
m>1.0\end{array}$ & $<1.7$ & \\
\hline
\end{tabular}


lowest mortality rate in women was observed in Finland and Greece (113 and 114 deaths $/ 100,000$ women alive, respectively). In general, the differences between the mortality rates from $\mathrm{MN}$ in women across the different European countries were rather small. In men, the highest mortality rate from $\mathrm{MN}$ was found in Lithuania followed by Latvia and Slovenia (306, 291 and 288 deaths/100,000 men alive, respectively). Compared to the results of women, the lowest rate of deaths from $\mathrm{MN}$ in men was found in Finland (178 deaths/100,000 men alive). In all European countries, men died more often from $\mathrm{MN}$ than women.

\section{Incidence of Malignant Neoplasms}

To illustrate the annual incidence of MN, the GLOBOCAN database 2002 was used (fig. 8.5-8.7) [Ferlay et al., 2004]. Within this database, data from 24 European countries are included and estimates for the year 2002 are presented. These estimates are based on the most recent data available at the International Agency for Research on Cancer in Lyon (IARC), but more recent data could be available from other sources. However, this database was used because other available databases deliver information from only a few countries.

Except for Denmark, the incidence of MN was higher in men than in women across all European countries (fig. 8.5). The order of the countries regarding the incidence of $\mathrm{MN}$ was different in men and women. In women, the highest incidence of $\mathrm{MN}$ was found in Denmark (496 new cases/100,000 inhabitants) followed by Germany and Sweden (467 and 464 new cases/100,000 inhabitants, respectively), whereas the highest incidence of MN in men was observed in Italy (586 new cases/100,000 inhabitants) followed by Belgium and Hungary (585 and 560 new cases/100,000 inhabitants, respectively). The lowest incidence of $\mathrm{MN}$ was found in Romania for both women and men (243 and 297 new cases/100,000 inhabitants, respectively).

The incidence of $\mathrm{MN}$ of the stomach was higher in men in comparison with women across Europe (fig. 8.6). The highest incidences of $\mathrm{MN}$ of the stomach were found in Portugal and Estonia for both women and men. The lowest incidence of MN of the stomach was observed in Denmark in women and men, respectively 8 and 13 new cases/100,000 inhabitants.

The incidence of $\mathrm{MN}$ of the colon and rectum across Europe are shown in fig. 8.6. In most countries the incidence of new cases was higher in men compared to women. But these differences were smaller compared with the incidence of MN of the stomach. In women, the highest incidence of $\mathrm{MN}$ of the colon and rectum was found in Germany and Norway (77 and 74 new cases/100,000 inhabitants, respectively). In men, the highest incidence of $\mathrm{MN}$ of the colon and rectum was observed for the Czech Republic and Hungary (88 and 85 new cases/100,000 inhabitants). The lowest incidence for both women and men was found in Romania (25 and 32 new cases/100,000 inhabitants, respectively).

Particularly large differences between women and men were found for the incidence of $\mathrm{MN}$ of the lung (fig. 8.7). Men showed up to 9 times higher rates in 

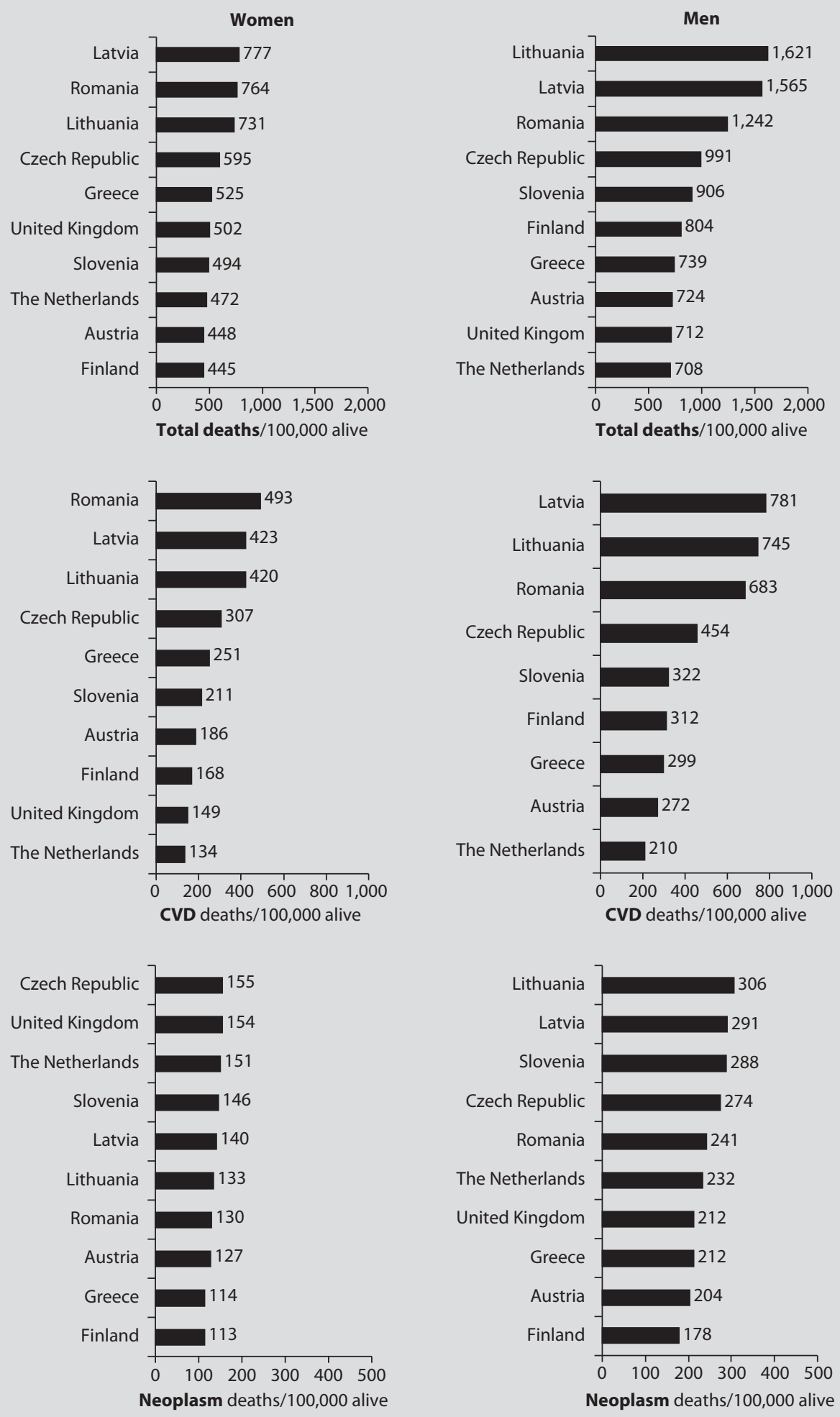

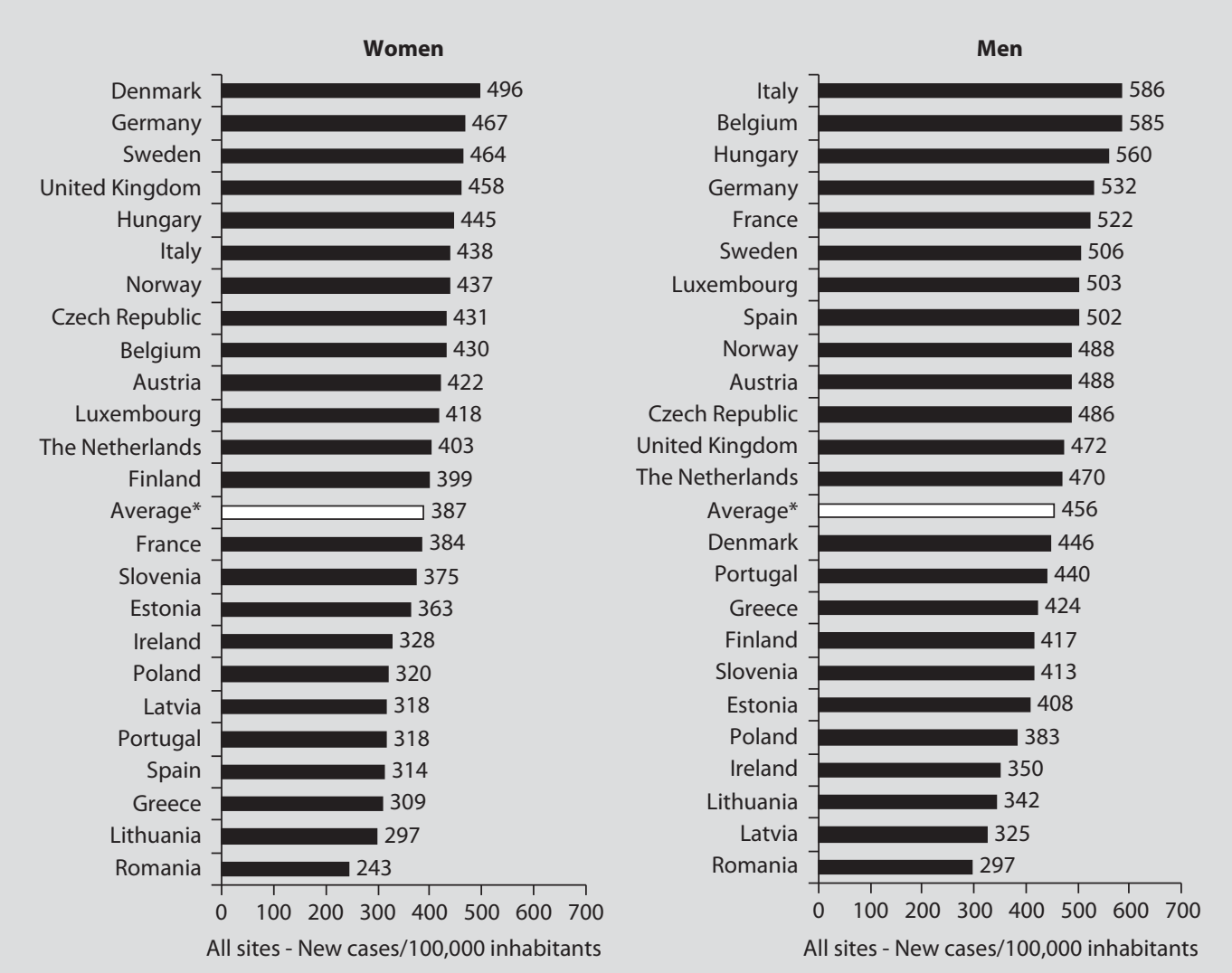

Fig. 8.5. Incidence of $\mathbf{M N}$ (excl. skin) in European countries indicated as new cases/100,000 inhabitants. Source: GLOBOCAN 2002 [Ferlay et al., 2004]. *Average of countries.

comparison with women. This corresponds with the results of smoking behavior (tables 8.5-8.10), showing that men smoked more often than women and that the proportion of ex-smokers was particularly high in older men. The highest incidence of MN of the lung in women was found in Denmark and the UK (56 and 51 new cases/100,000 inhabitants, respectively), whereas the highest incidence in men was observed in Hungary and Belgium (138 and 130 new cases/100,000 inhabitants, respectively). The lowest incidence was found in Spanish women and in Swedish men (10 and 40 new cases/100,000 inhabitants, respectively).

Except for Sweden, Finland, Norway, Austria and Portugal, all European countries showed a higher incidence of $\mathrm{MN}$ of the breast in comparison with $\mathrm{MN}$ of the prostate. The highest incidences of $\mathrm{MN}$ of the breast and prostate were found in

Fig. 8.4. Total mortality rate, mortality from CVD and from neoplasms (deaths/100,000 alive) in 2007 in European countries. Source: European Health-for-All database. Copenhagen, WHO Regional Office for Europe, 2009a. 


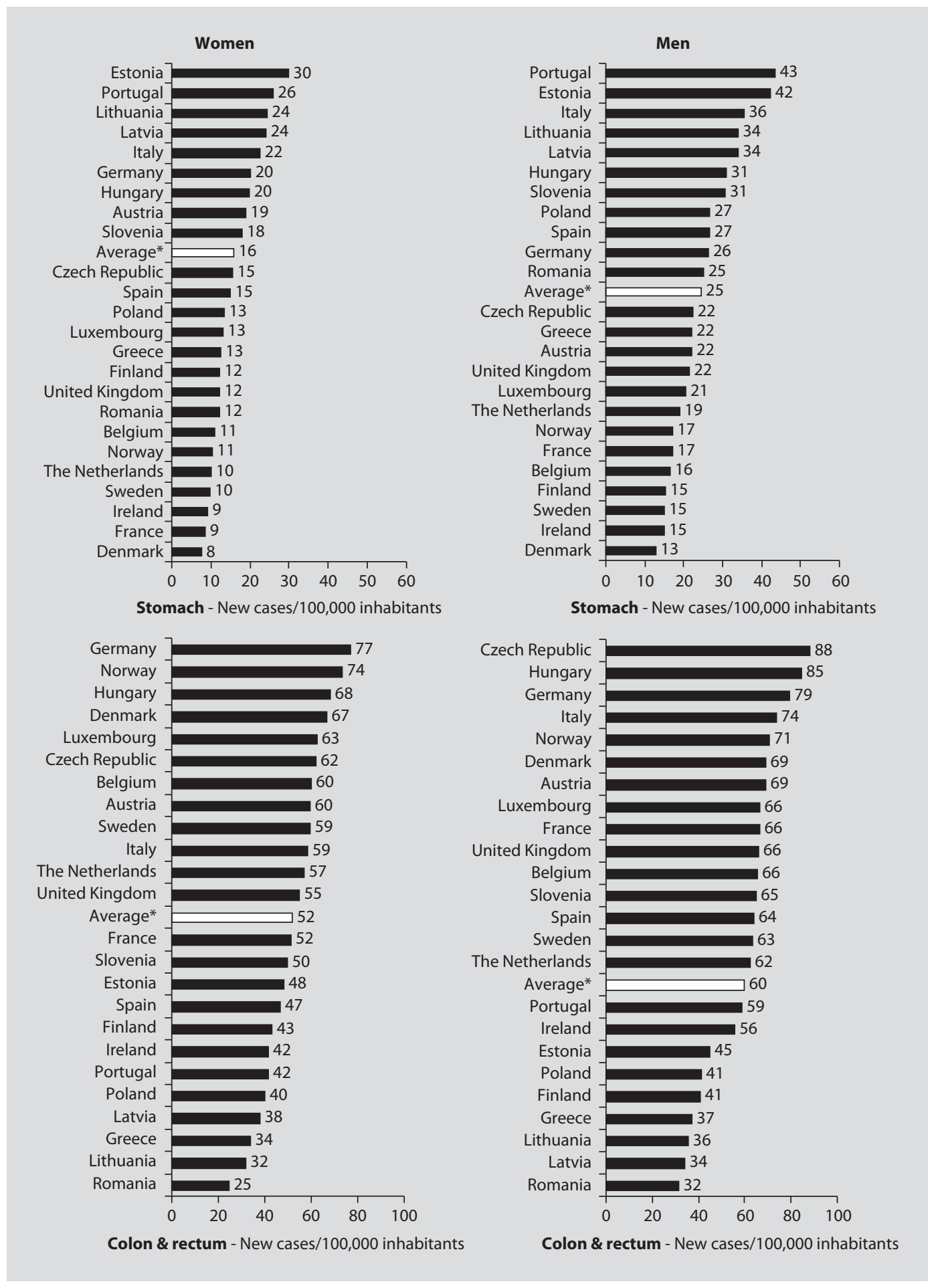

Fig. 8.6. Incidence of $M N$ of the stomach and colon and rectum in European countries indicated as new cases/100,000 inhabitants. Source: GLOBOCAN 2002 [Ferlay et al., 2004]. *Average of countries. 


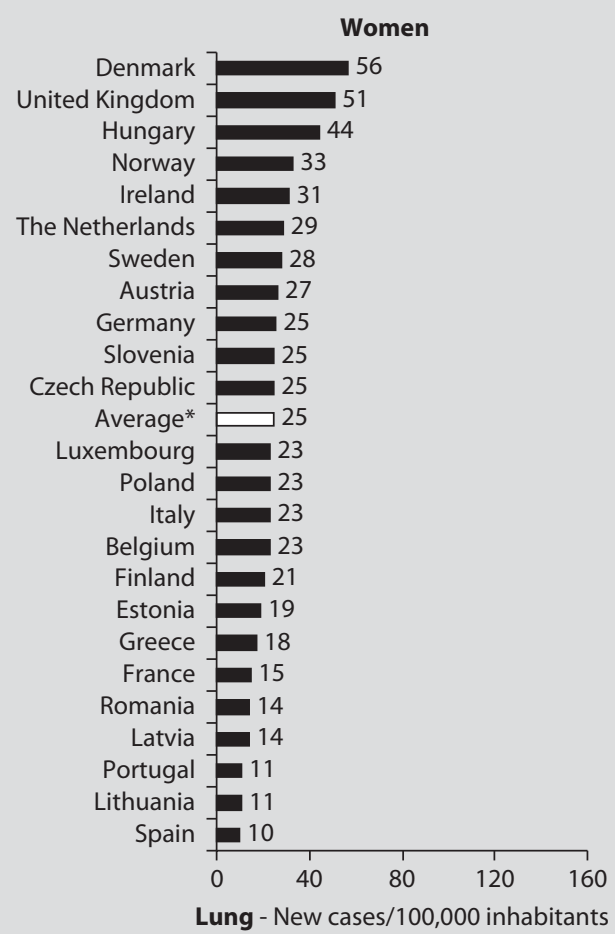

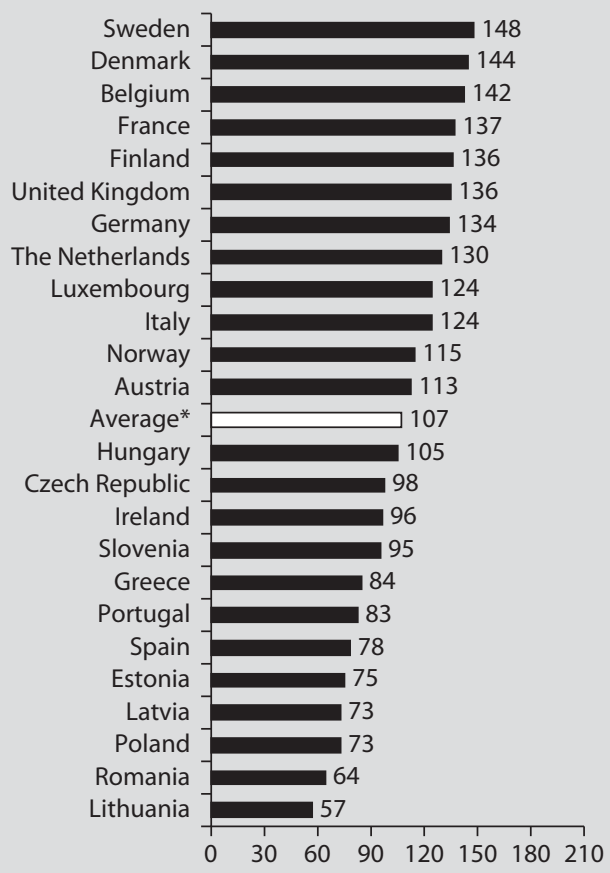

Breast - New cases/100,000 inhabitants
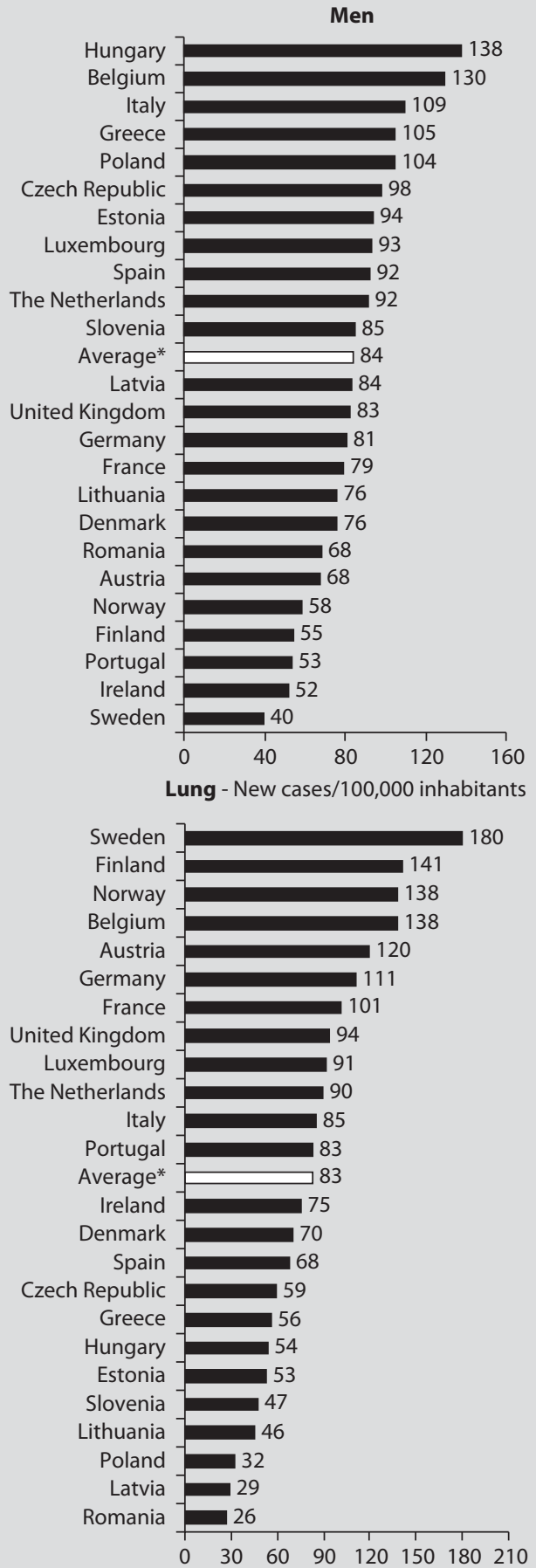

Prostate - New cases/100,000 inhabitants

Fig. 8.7. Incidence of $\mathbf{M N}$ of the lung, prostate and breast in European countries indicated as new cases/100,000 inhabitants. Source: GLOBOCAN 2002 [Ferlay et al., 2004]. *Average of countries. 
Table 8.10. Proportion of smokers and ex-smokers in different European countries, women and men 19-41 years of age

\begin{tabular}{|c|c|c|c|c|c|c|}
\hline \multirow[t]{2}{*}{ Country } & \multirow[t]{2}{*}{ Survey name } & \multirow[t]{2}{*}{ Survey year } & \multicolumn{2}{|l|}{ Women } & \multicolumn{2}{|l|}{ Men } \\
\hline & & & $\begin{array}{l}\text { current } \\
\text { smokers \% }\end{array}$ & $\begin{array}{l}\text { ex- } \\
\text { smokers \% }\end{array}$ & $\begin{array}{l}\text { current } \\
\text { smokers \% }\end{array}$ & $\begin{array}{l}\text { ex- } \\
\text { smokers \% }\end{array}$ \\
\hline Austria & $\begin{array}{l}\text { Austrian Study on Nutritional } \\
\text { Status - ÖSES.pal07 }\end{array}$ & 2007 & 16.4 & 52.4 & 20.8 & 42.2 \\
\hline Belgium & Health Interview Survey & 2004 & 29.5 & 13.8 & 37.7 & 12.4 \\
\hline Czech Republic & & & 28.1 & 13.9 & 39.3 & 13.9 \\
\hline Denmark & $\begin{array}{l}\text { Danish National Survey on } \\
\text { Dietary Habits and Physical } \\
\text { Activity }\end{array}$ & 2000-2002 & 38.1 & 15.0 & 36.3 & 13.6 \\
\hline Estonia & $\begin{array}{l}\text { Estonian Health Interview } \\
\text { Survey }\end{array}$ & 2006 & 23.5 & 9.6 & 46.8 & 15.4 \\
\hline Finland $^{1}$ & FINRISK Study & 2002 & 28.0 & 15.5 & 29.0 & \\
\hline France & $\begin{array}{l}\text { French Nutrition and Health } \\
\text { Survey }\end{array}$ & 2006-2007 & 36.8 & 20.1 & 44.8 & 18.4 \\
\hline Germany & $\begin{array}{l}\text { German National Nutrition } \\
\text { Survey II }\end{array}$ & 2005-2007 & 33.6 & 14.3 & 44.3 & 14.6 \\
\hline Greece & EPIC Study & 1994-1999 & 42.3 & 8.7 & 57.8 & 18.1 \\
\hline Ireland $^{2}$ & $\begin{array}{l}\text { Dietary Habits of the Irish } \\
\text { Population }\end{array}$ & 2007 & 30.5 & & 37.5 & \\
\hline Italy & $\begin{array}{l}\text { Italian National Food } \\
\text { Consumption Survey }\end{array}$ & 2005-2006 & 7.0 & 6.0 & 8.0 & 8.0 \\
\hline Lithuania & $\begin{array}{l}\text { Health Behaviour among } \\
\text { Lithuanian Adult Population }\end{array}$ & 2008 & 17.2 & 8.6 & 43.0 & 12.1 \\
\hline Portugal $^{3}$ & National Health Survey & 2005-2006 & 19.8 & 9.7 & 41.8 & 15.3 \\
\hline Spain & Catalan Nutrition Survey & $2002-2003$ & 41.6 & 17.4 & 47.3 & 12.7 \\
\hline Sweden & $\begin{array}{l}\text { Dietary Habits and Nutrient } \\
\text { Intake in Sweden }\end{array}$ & 1997-1998 & 24.0 & 18.0 & 10.0 & 19.0 \\
\hline The Netherlands ${ }^{4}$ & Statistics Netherlands, Statline & 2007 & 27.9 & & 38.3 & \\
\hline \multirow[t]{3}{*}{$\mathrm{UK}^{5}$} & General Household Survey & 2006 a) & 29.0 & 11.0 & 33.0 & 11.0 \\
\hline & & b) & 26.0 & 17.0 & 33.0 & 16.0 \\
\hline & & c) & 25.0 & 18.0 & 26.0 & 20.0 \\
\hline
\end{tabular}

\footnotetext{
${ }^{1}$ Age: $25-44$ years.
}

${ }^{2}$ Age: $18-44$ years.

${ }^{3}$ Age: $20-44$ years.

${ }^{4}$ Age: $25-44$ years.

${ }^{5}$ Age: a) 20-24 years, b) 25-34 years, c) 35-49 years. 


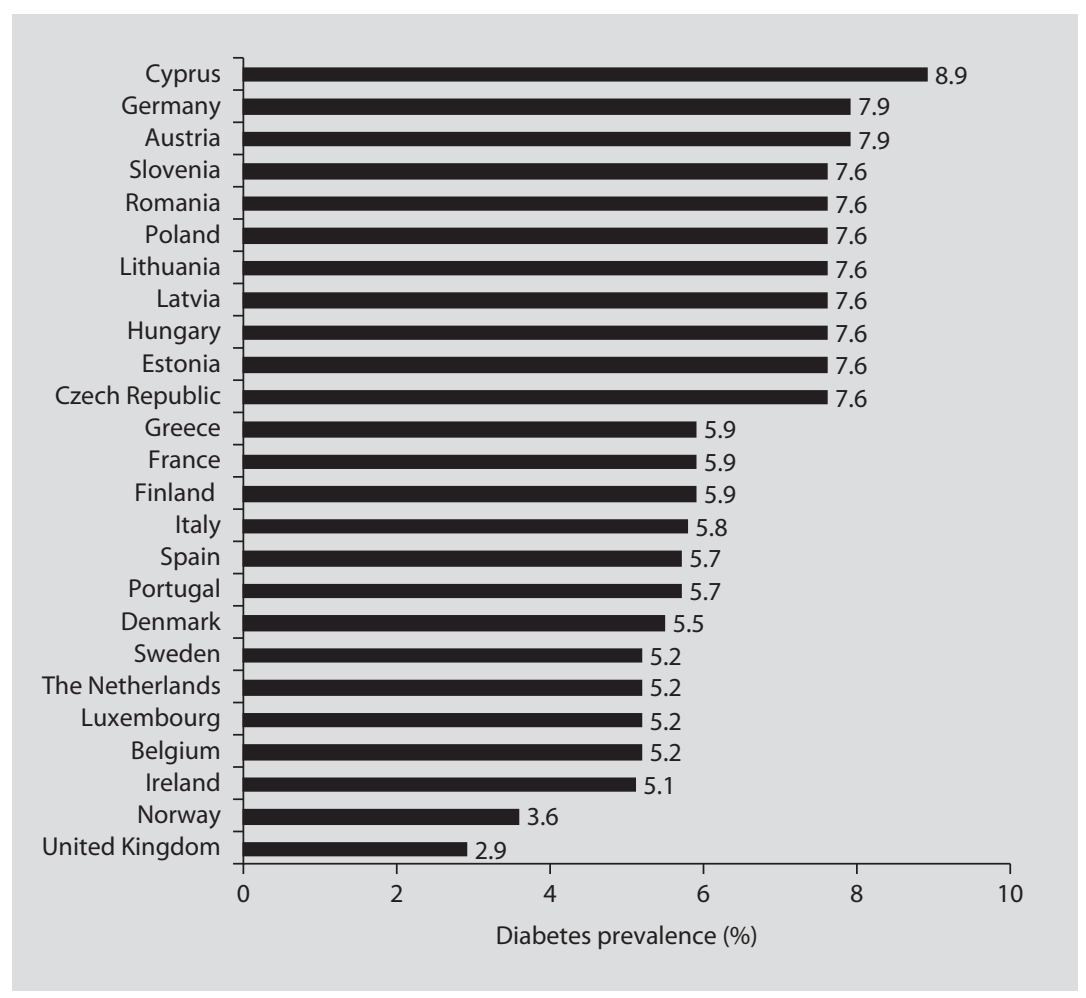

Fig. 8.8. Prevalence of DM type 1 and 2 of European countries (males and females) in 2007. Source: IDF, 2009.

Sweden (148 and 180 new cases/100,000 inhabitants, respectively) (fig. 8.7). The lowest incidence of $\mathrm{MN}$ of the breast was found in Lithuania and Romania (57 and 64 new cases/100,000 inhabitants, respectively) and the lowest incidence of $\mathrm{MN}$ of the prostate was observed in Romania and Latvia (26 and 29 new cases/100,000 inhabitants, respectively).

\section{Prevalence of Diabetes Mellitus}

Data from the International Diabetes Federation (IDF) 2009 are used to present the prevalence of Diabetes mellitus (DM) (types 1 and 2) in European countries (fig. 8.8). Therefore, literature, which was published before March 2006, was collected within the database Medline and the internet. Additionally the members of the IDF were asked for relevant data. If there were no data available for one country, data were extrapolated. In 2007, information about DM was obtainable from 25 European countries but not separately for women and men. The highest prevalence was found in Cyprus with $8.9 \%$ of the total population. The lowest prevalence was observed in the UK with $2.9 \%$ of the total population, followed by Norway with a prevalence of $\mathrm{DM}$ of 3.5\%. The other countries built two sections. The countries which correspond 
to one section showed a prevalence of DM with $5.1-5.9 \%$ of the total population and for the countries of the other section a higher prevalence of DM between 7.6 and $7.9 \%$ with only minor differences was observed.

\subsection{Smoking Behavior}

Data about smoking behavior were available for both women and men from 15 to 17 countries across the European Union. In tables 8.10-8.12, proportions of smokers and ex-smokers in the different countries are shown separately for young adults, adults of middle age and elderly.

In most countries, the proportion of smokers was higher in men compared with women for all age groups. In Sweden, adult women smoked more often than men. This survey was conducted in 1997/1998, whereas the data collection of the other surveys took place between 2002 and 2008. In addition, the proportion of smokers was a little bit higher in young adult women in Denmark in comparison with young adult men as well as in elderly Austrian women in comparison with elderly Austrian men.

The highest proportion of smokers was found among adult men across the European Union, particularly in young adult men in Greece with $57.8 \%$, whereas the highest proportion of ex-smokers was shown in elderly men. Across all countries a reduction of smoking was observed from the younger to the older age groups except for Danish men. Danish men showed nearly the same proportion of smokers in all age groups. Elderly men showed a higher proportion of ex-smokers in comparison with adult men. In elderly women, the proportion of ex-smokers was particularly low. The proportion of smokers was notably low in Italy for all age groups in comparison with the other countries (3.0-9.0\%).

\subsection{Alcohol Consumption}

Data on alcohol consumption (g/day) was available from 14 European countries (table 8.13). The average alcohol consumption of women was $<10 \mathrm{~g} /$ day in all European countries except for adult and elderly Danish women and middleaged women from The Netherlands. In women, the highest alcohol consumption was found for elderly Danish women with $14.0 \mathrm{~g} /$ day. In men, the average alcohol consumption was $<20 \mathrm{~g} /$ day across the European countries except for men from Portugal and Ireland as well as Danish adult and elderly men. Accordingly, the highest alcohol consumption was found for Portuguese men with $31.8 \mathrm{~g} /$ day.

Table 8.13 shows the proportions of alcohol abstainers from 8 to 9 European countries for adults and elderly. The proportion of alcohol abstainers differed widely between the European countries. This can be explained by the fact that the definition

of alcohol abstainers in the studies might have been different. The highest proportion 
Table 8.11. Proportion of smokers and ex-smokers in different European countries, women and men 42-64 years of age

\begin{tabular}{|c|c|c|c|c|c|c|}
\hline \multirow[t]{2}{*}{ Country } & \multirow[t]{2}{*}{ Survey name } & \multirow[t]{2}{*}{ Survey year } & \multicolumn{2}{|l|}{ Women } & \multicolumn{2}{|l|}{ Men } \\
\hline & & & $\begin{array}{l}\text { current } \\
\text { smokers \% }\end{array}$ & $\begin{array}{l}\text { ex- } \\
\text { smokers \% }\end{array}$ & $\begin{array}{l}\text { current } \\
\text { smokers \% }\end{array}$ & $\begin{array}{l}\text { ex- } \\
\text { smokers \% }\end{array}$ \\
\hline Austria & $\begin{array}{l}\text { Austrian Study on Nutritional } \\
\text { Status - ÖSES.pal07 }\end{array}$ & 2007 & 26.7 & 51.5 & 27.2 & 50.3 \\
\hline Belgium & Health Interview Survey & 2004 & 24.8 & 20.6 & 34.6 & 31.5 \\
\hline Czech Republic & & & 24.9 & 14.3 & 35.2 & 32.6 \\
\hline Denmark & $\begin{array}{l}\text { Danish National Survey on } \\
\text { Dietary Habits and Physical } \\
\text { Activity }\end{array}$ & $2000-2002$ & 35.5 & 39.6 & 38.1 & 32.4 \\
\hline Estonia & $\begin{array}{l}\text { Estonian Health Interview } \\
\text { Survey }\end{array}$ & 2006 & 18.1 & 13.0 & 44.0 & 25.1 \\
\hline France & $\begin{array}{l}\text { French Nutrition and Health } \\
\text { Survey }\end{array}$ & 2006-2007 & 23.1 & 19.7 & 29.0 & 43.8 \\
\hline Germany & $\begin{array}{l}\text { German National Nutrition } \\
\text { Survey II }\end{array}$ & 2005-2007 & 27.1 & 22.5 & 35.0 & 30.9 \\
\hline Greece & EPIC Study & 1994-1999 & 15.4 & 5.9 & 42.5 & 33.0 \\
\hline Ireland ${ }^{1}$ & $\begin{array}{l}\text { Dietary Habits of the Irish } \\
\text { Population }\end{array}$ & 2007 & 27.0 & & 23.0 & \\
\hline Italy & $\begin{array}{l}\text { Italian National Food } \\
\text { Consumption Survey }\end{array}$ & 2005-2006 & 7.0 & 12.0 & 9.0 & 24.0 \\
\hline Lithuania & $\begin{array}{l}\text { Health Behaviour among } \\
\text { Lithuanian Adult Population }\end{array}$ & 2008 & 11.5 & 7.9 & 34.1 & 24.9 \\
\hline Portugal $^{1}$ & National Health Survey & 2005-2006 & 9.3 & 7.3 & 20.0 & 12.5 \\
\hline Spain & Catalan Nutrition Survey & $2002-2003$ & 18.5 & 21.3 & 31.6 & 36.1 \\
\hline Sweden & $\begin{array}{l}\text { Dietary Habits and Nutrient } \\
\text { Intake in Sweden }\end{array}$ & 1997-1998 & 27.0 & 32.0 & 17.0 & 35.0 \\
\hline The Netherlands ${ }^{1}$ & Statistics Netherlands, Statline & 2007 & 26.7 & & 32.4 & \\
\hline UK & General Household Survey & 2006 & 22.0 & 25.0 & 23.0 & 31.0 \\
\hline
\end{tabular}

${ }^{1}$ Age: $45-64$ years.

of alcohol abstainers for adults showed Romania and the lowest proportions of alcohol abstainers for adults were found in Estonia and Germany. The highest proportions of alcohol abstainers for elderly women and men were found in Lithuania and Romania. The lowest proportions of alcohol abstainers in elderly women and men 
Table 8.12. Proportion of smokers and ex-smokers in different European countries, women and men $\mathbf{6 5 +}$ years of age

\begin{tabular}{|c|c|c|c|c|c|c|}
\hline \multirow[t]{2}{*}{ Country } & \multirow[t]{2}{*}{ Survey name } & \multirow[t]{2}{*}{ Survey year } & \multicolumn{2}{|l|}{ Women } & \multicolumn{2}{|l|}{ Men } \\
\hline & & & $\begin{array}{l}\text { current } \\
\text { smokers \% }\end{array}$ & $\begin{array}{l}\text { ex- } \\
\text { smokers \% }\end{array}$ & $\begin{array}{l}\text { current } \\
\text { smokers \% }\end{array}$ & $\begin{array}{l}\text { ex- } \\
\text { smokers \% }\end{array}$ \\
\hline Austria & $\begin{array}{l}\text { Austrian Study on Nutritional } \\
\text { Status - ÖSES.sen } 07\end{array}$ & 2007 & 5.1 & 8.9 & 3.5 & 62.3 \\
\hline Belgium & Health Interview Survey & 2004 & 9.2 & 12.0 & 19.6 & 44.7 \\
\hline Denmark & $\begin{array}{l}\text { Danish National Survey on } \\
\text { Dietary Habits and Physical } \\
\text { Activity }\end{array}$ & $2000-2002$ & 31.5 & 32.1 & 36.5 & 47.6 \\
\hline Estonia & $\begin{array}{l}\text { Estonian Health Interview } \\
\text { Survey }\end{array}$ & 2006 & 4.1 & 6.1 & 20.1 & 43.6 \\
\hline France & $\begin{array}{l}\text { French Nutrition and Health } \\
\text { Survey }\end{array}$ & 2006-2007 & 5.6 & 10.0 & 9.8 & 53.2 \\
\hline Germany & $\begin{array}{l}\text { German National Nutrition } \\
\text { Survey II }\end{array}$ & 2005-2007 & 7.7 & 15.6 & 12.6 & 46.0 \\
\hline Greece & EPIC Study & 1994-1999 & 2.2 & 3.0 & 22.6 & 46.4 \\
\hline Ireland & $\begin{array}{l}\text { Dietary Habits of the Irish } \\
\text { Population }\end{array}$ & 2007 & 13.0 & & 17.0 & \\
\hline Italy & $\begin{array}{l}\text { Italian National Food } \\
\text { Consumption Survey }\end{array}$ & 2005-2006 & 3.0 & 9.0 & 5.0 & 41.0 \\
\hline \multirow[t]{2}{*}{ Lithuania } & Health Survey & 2005 a) & 1.3 & 2.9 & 22.7 & 37.1 \\
\hline & & b) & 0.4 & 3.8 & 11.1 & 54.3 \\
\hline Portugal & National Health Survey & 2005-2006 & 0.9 & 1.4 & 10.5 & 43.7 \\
\hline Spain & Catalan Nutrition Survey & 2002-2003 & 4.5 & 4.5 & 17.2 & 56.4 \\
\hline Sweden & $\begin{array}{l}\text { Dietary Habits and Nutrient } \\
\text { Intake in Sweden }\end{array}$ & 1997-1998 & 9.0 & 21.0 & 12.0 & 45.0 \\
\hline The Netherlands & Statistics Netherlands, Statline & 2007 & 14.3 & & 19.9 & \\
\hline UK$^{2}$ & General Household Survey & 2006 & 12.0 & 30.0 & 13.0 & 49.0 \\
\hline
\end{tabular}

${ }^{1}$ Age: a) 65-74 years, b) $\geq 75$ years.

${ }^{2}$ Age: $\geq 60$ years 
Table 8.13. Alcohol consumption in different European countries, women and men

\begin{tabular}{|c|c|c|c|c|c|c|c|c|c|c|c|}
\hline \multirow[t]{3}{*}{ Country } & \multirow[t]{3}{*}{ Survey name } & \multirow[t]{3}{*}{ Survey year } & \multirow{3}{*}{$\begin{array}{l}\text { Age } \\
\text { years }\end{array}$} & \multicolumn{4}{|l|}{ Women } & \multicolumn{4}{|l|}{ Men } \\
\hline & & & & \multirow[t]{2}{*}{$\mathrm{n}$} & \multicolumn{3}{|c|}{$\begin{array}{l}\text { alcohol consumption } \\
\text { g/day }\end{array}$} & \multirow[t]{2}{*}{$\mathrm{n}$} & \multicolumn{3}{|c|}{$\begin{array}{l}\text { alcohol consumption } \\
\text { g/day }\end{array}$} \\
\hline & & & & & mean $\pm S D$ & P50 & P95 & & mean $\pm S D$ & P50 & P95 \\
\hline Austria & $\begin{array}{l}\text { Austrian Study on } \\
\text { Nutritional Status }\end{array}$ & 2007 & $19-64$ & 1,345 & $3.6 \pm 8.7$ & 0.0 & 21.1 & 778 & $10.8 \pm 20.4$ & 0.3 & 59.4 \\
\hline Czech Republic & & & $19-64$ & 1,094 & $3.1 \pm 6.5$ & 0.0 & 12.5 & 1,046 & $18.1 \pm 19.9$ & 12.1 & 55.7 \\
\hline \multirow[t]{3}{*}{ Denmark } & $\begin{array}{l}\text { Danish National } \\
\text { Survey on } \\
\text { Dietary Habits } \\
\text { and Physical } \\
\text { Activity }\end{array}$ & 2000-2002 & $15-18$ & 121 & $5.6 \pm 10.4$ & 0.0 & 30.3 & 78 & $11.3 \pm 19.0$ & 3.2 & 47.7 \\
\hline & & & $19-64$ & 1,486 & $12.9 \pm 13.0$ & 9.5 & 39.1 & 1,283 & $25.5 \pm 24.4$ & 19.7 & 68.1 \\
\hline & & & $65-75$ & 164 & $14.0 \pm 12.8$ & 12.3 & 38.1 & 165 & $28.6 \pm 23.2$ & 23.7 & 70.1 \\
\hline Estonia & $\begin{array}{l}\text { Estonian Health } \\
\text { Interview Survey }\end{array}$ & 2006 & $15-64$ & 3,323 & $2.3 \pm 6.2$ & 1.0 & 8.7 & 3,111 & $12.8 \pm 34.4$ & 5.0 & 13.7 \\
\hline France & $\begin{array}{l}\text { French Nutrition } \\
\text { and Health } \\
\text { Survey }\end{array}$ & 2007-2007 & 19-74 & 2,483 & $4.9 \pm 0.3$ & 1.0 & 21.4 & 1,585 & $16.6 \pm 0-9$ & 10.1 & 54.8 \\
\hline Germany & $\begin{array}{l}\text { German National } \\
\text { Nutrition } \\
\text { Survey II }\end{array}$ & 2005-2007 & $15-80$ & 8,183 & $5.2 \pm 8.2$ & 2.1 & 20.9 & 6,976 & $15.3 \pm 19.7$ & 9.2 & 51.0 \\
\hline \multirow[t]{2}{*}{ Greece } & EPIC Study & 1994-1999 & $16-64$ & 12,043 & $3.5 \pm 6.4$ & 1.2 & 15.7 & 8,365 & $19.6 \pm 25.3$ & 11.5 & 66.5 \\
\hline & & & $\geq 65$ & 3,600 & $2.3 \pm 5.2$ & 0.1 & 10.2 & 2,508 & $13.9 \pm 20.0$ & 7.9 & 49.4 \\
\hline Hungary & Dietary Survey & 2003-2004 & $\geq 19$ & 706 & $6.7 \pm 5.9$ & & & 473 & $15.4 \pm 13.3$ & & \\
\hline Ireland & $\begin{array}{l}\text { North/South } \\
\text { Ireland Food } \\
\text { Consumption } \\
\text { Survey }\end{array}$ & 1997-1999 & $18-64$ & 698 & $9.3 \pm 13.0$ & & & 613 & $22.9 \pm 29.8$ & & \\
\hline Italy & $\begin{array}{l}\text { Italian National } \\
\text { Food } \\
\text { Consumption } \\
\text { Survey }\end{array}$ & 2005-2006 & & 1,822 & $4.5 \pm 8.3$ & 0.0 & 23.8 & 1,501 & $12.4 \pm 16.6$ & 4.3 & 44.3 \\
\hline Latvia & $\begin{array}{l}\text { Nutrition and } \\
\text { Lifestyle in the } \\
\text { Baltic Republics }\end{array}$ & 1997 & $15-64$ & 1,235 & $3.0 \pm 7.0$ & & & 1,065 & $15.0 \pm 24.0$ & & \\
\hline
\end{tabular}


Table 8.13. Continued

\begin{tabular}{|c|c|c|c|c|c|c|c|c|c|c|c|}
\hline \multirow[t]{3}{*}{ Country } & \multirow[t]{3}{*}{ Survey name } & \multirow[t]{3}{*}{ Survey year } & \multirow{3}{*}{$\begin{array}{l}\text { Age } \\
\text { years }\end{array}$} & \multicolumn{4}{|c|}{ Women } & \multicolumn{4}{|l|}{ Men } \\
\hline & & & & \multirow[t]{2}{*}{$n$} & \multicolumn{3}{|c|}{$\begin{array}{l}\text { alcohol consumption } \\
\text { g/day }\end{array}$} & \multirow[t]{2}{*}{$\mathrm{n}$} & \multicolumn{3}{|c|}{$\begin{array}{l}\text { alcohol consumption } \\
\text { g/day }\end{array}$} \\
\hline & & & & & mean $\pm S D$ & P50 & P95 & & mean $\pm S D$ & P50 & P95 \\
\hline Lithuania & $\begin{array}{l}\text { Health Behavior } \\
\text { among Lithuanian } \\
\text { Adult Population }\end{array}$ & 2006 & $20-65$ & 1,016 & $1.7 \pm 3.6$ & 0.4 & 6.9 & 723 & $16.4 \pm 31.6$ & 8.3 & 56.7 \\
\hline Norway & Norkost Study & 1997 & $19-65$ & 1,208 & $3.9 \pm 6.0$ & 1.9 & 14.1 & 1,122 & $8.3 \pm 12.6$ & 4.8 & 27.5 \\
\hline Portugal & EPI Porto & & $\geq 18$ & 1,472 & $6.8 \pm 11.9$ & & 29.0 & 917 & $31.8 \pm 31.6$ & & 93.2 \\
\hline Spain & $\begin{array}{l}\text { Catalan Nutrition } \\
\text { Survey }\end{array}$ & 2002-2003 & $\geq 15$ & 1,111 & $2.6 \pm 5.2$ & 0.5 & 12.4 & 930 & $8.4 \pm 12.2$ & 3.0 & 30.1 \\
\hline Sweden & $\begin{array}{l}\text { Dietary Habits } \\
\text { and Nutrient } \\
\text { Intake in Sweden }\end{array}$ & 1997-1998 & & & $7.6 \pm 9.8$ & 5.0 & 23.2 & & $12.7 \pm 13.4$ & 9.4 & 39.8 \\
\hline \multirow[t]{5}{*}{$\begin{array}{l}\text { The } \\
\text { Netherlands }\end{array}$} & $\begin{array}{l}\text { Dutch National } \\
\text { Food } \\
\text { Consumption } \\
\text { Survey-3 }\end{array}$ & 1997/1998 & $16-18$ & 139 & $3.0 \pm 7.0$ & 0.0 & 17.0 & 142 & $8.0 \pm 19.0$ & 0.0 & 44.0 \\
\hline & & & $19-21$ & 128 & $3.0 \pm 9.0$ & 0.0 & 18.0 & 130 & $14.0 \pm 27.0$ & 0.0 & 66.0 \\
\hline & & & $22-49$ & 1,472 & $8.0 \pm 15.0$ & 0.0 & 38.0 & 1,252 & $18.0 \pm 24.0$ & 9.0 & 66.0 \\
\hline & & & $50-64$ & 512 & $10.0 \pm 15.0$ & 0.0 & 40.0 & 454 & $19.0 \pm 22.0$ & 12.0 & 63.0 \\
\hline & & & $\geq 65$ & 236 & $6.0 \pm 11.0$ & 0.0 & 30.0 & 185 & $17.0 \pm 20.0$ & 12.0 & 51.0 \\
\hline
\end{tabular}

$\mathrm{P} 50=50$ th percentile, $\mathrm{P95}=$ 95 th percentile.

were observed in Germany and France. In addition, elderly men from Estonia showed a low proportion of alcohol abstainers.

\subsection{Overview of European Cross-National Data on Physical Activity²}

Concept of Health-Enhancing Physical Activity - Recommendations and Surveillance Current public health recommendations state that adults should engage in a minimum of 30 minutes of moderate-intensity aerobic (endurance) physical activity on

${ }^{2}$ Rütten A, Abu-Omar K, Gelius P: Institute of Sport Science and Sport, FAU Erlangen-Nuremberg (alfred.ruetten@sport.uni-erlangen.de). 
5 days per week, or in vigorous aerobic physical activity for a minimum of 20 minutes on 3 days per week. Additionally, adults should engage in activities to increase muscular strength on 2 days per week [Haskell et al., 2007].

Since 1997, public health recommendations for physical activity issued by the American College of Sport Medicine (ACSM) have shifted from a specific focus on exercise-related physical activity to the broader concept of physical activity integrated in daily living [Pate et al., 1997]. Within this concept, types of physical activity that have beneficial health effects (health-enhancing physical activity (HEPA)) can take place in the domains of work, transportation/commuting, at home, or during leisuretime. The expansion of the old concept of exercise to the current concept of daily physical activity was warranted by increasing evidence about the health benefits of physical activities of moderate intensity [Blair et al., 1992].

Regarding the assessment of physical activity on the population level, the HEPA concept has stimulated the development of questionnaires that allow for the assessment of physical activity during leisure-time and in the three other domains (work, transport, home). Most prominently, the International Physical Activity Questionnaire (IPAQ) and the Global Physical Activity Questionnaire (GPAQ) have been designed to capture physical activity across all domains. Both questionnaires have been tested for reliability and validity in international studies [IPAQ: Craig et al., 2003; GPAQ: Armstrong and Bull, 2006] and have been shown to have measurement properties comparable to other self-assessment instruments utilized to assess physical activity.

\section{Limitations of Physical Activity Assessment}

In general, one has to acknowledge that self-assessment of physical activity suffers from a number of limitations and that attempts to make assessments across different domains might have contributed to difficulties in generating robust cross-national surveillance data on physical activity. Among these limitations are (1) sensitivity of information on physical activity derived from respondents to wording differences in questions, (2) recall problems of respondents, especially regarding physical activity of moderate intensity, (3) potential over-reporting of the duration of physical activity bouts, (4) limited comparability of physical activity levels across nations and cultures due to differing physical activity concepts, and (5) limited comparability of results across surveys due to methodological peculiarities of studies.

\section{National Surveillance Systems in Europe}

On the national level, surveillance systems tracking the population's physical activity levels as part of behavioral risk factor assessment for chronic diseases have been adopted in a number of nations in the European region. While in some nations these surveillance systems were already established some 20 years ago and collect data annually (e.g. Finland), other nations have only recently established such systems (e.g. Italy), are still in the process of implementing such systems (e.g. Germany), or do not 
feature such systems at all. Some of these systems utilize a framework that was originally developed in the USA as part of the Behavioral Risk Factor Surveillance System. While these systems are generally useful to describe physical activity behavior within nations, data generated by these systems do not permit description of physical activity patterns across nations. This is mainly due to differences in the physical activity concepts operationalized (sport/exercise, HEPA), dimensions of physical activity assessed (e.g. type, duration, frequency, intensity), wording of survey questions, and response categories provided (e.g. Likert scales, duration in hours/minutes). The EUPASS project has demonstrated that such national surveillance instruments for physical activity assessment hardly yield any comparable results and that Spearman's rho correlation coefficient between the different survey instruments is in general low [Rütten et al., 2003]. In order to describe physical activity patterns across nations, it is thus advisable to rely on cross-national datasets instead.

\section{Cross-National Surveillance Systems in Europe}

Starting with the European Food Study [de Almeida et al., 1999; Martinez et al., 2001], the European Physical Activity Surveillance System [Rütten et al., 2003], Eurobarometer 58.2 [Rütten and Abu-Omar, 2004], Eurobarometer 62.0, Eurobarometer 64.3, Eurobarometer 67.3, and the European Health Interview Survey (EHIS), there are now numerous datasets available that allow to describe crossnational physical activity rates of populations in Europe. While each of these datasets yields important information on physical activity levels, it remains difficult to compare results across these surveys. Some studies assessed only leisure-time physical activity (e.g. European Food Study, Eurobarometer 62.0), while other studies utilize the IPAQ (e.g. Eurobarometer 58.2) or the IPAQ in slightly modified versions (Eurobarometer 64.3). For the European region, the IPAQ questionnaire has been the primary means to assess physical activity levels of populations in recent years.

\section{Adults - Selected Findings}

The following section highlights some of the findings regarding physical activity patterns that can be identified in the available cross-national datasets. The European Food Study assessed physical activity with the Paffenbarger questionnaire [Paffenbarger et al., 1978]. This questionnaire provides information on leisure-time physical activity and allows calculating metabolic equivalents (METs) in order to quantify the amount of leisure-time physical activity. Data were gathered in 1997 in the then $15 \mathrm{EU}$ member states by face-to-face interviews. In each nation, about 1,000 interviews were conducted. Fig. 8.9 indicates the percentage of adults reporting to practice any type of leisure-time physical activity. Overall, $73.1 \%$ of adults in the EU Member States reported they were engaging in leisure-time physical activity. The rate declined with age $(82.8 \%$ among respondents aged $15-24,64.5 \%$ among respondents $\geq 65$ years of age) and increased with educational attainment ( $64.1 \%$ of respondents with a degree lesser than high school, $81.4 \%$ of respondents with a high school degree or more). 


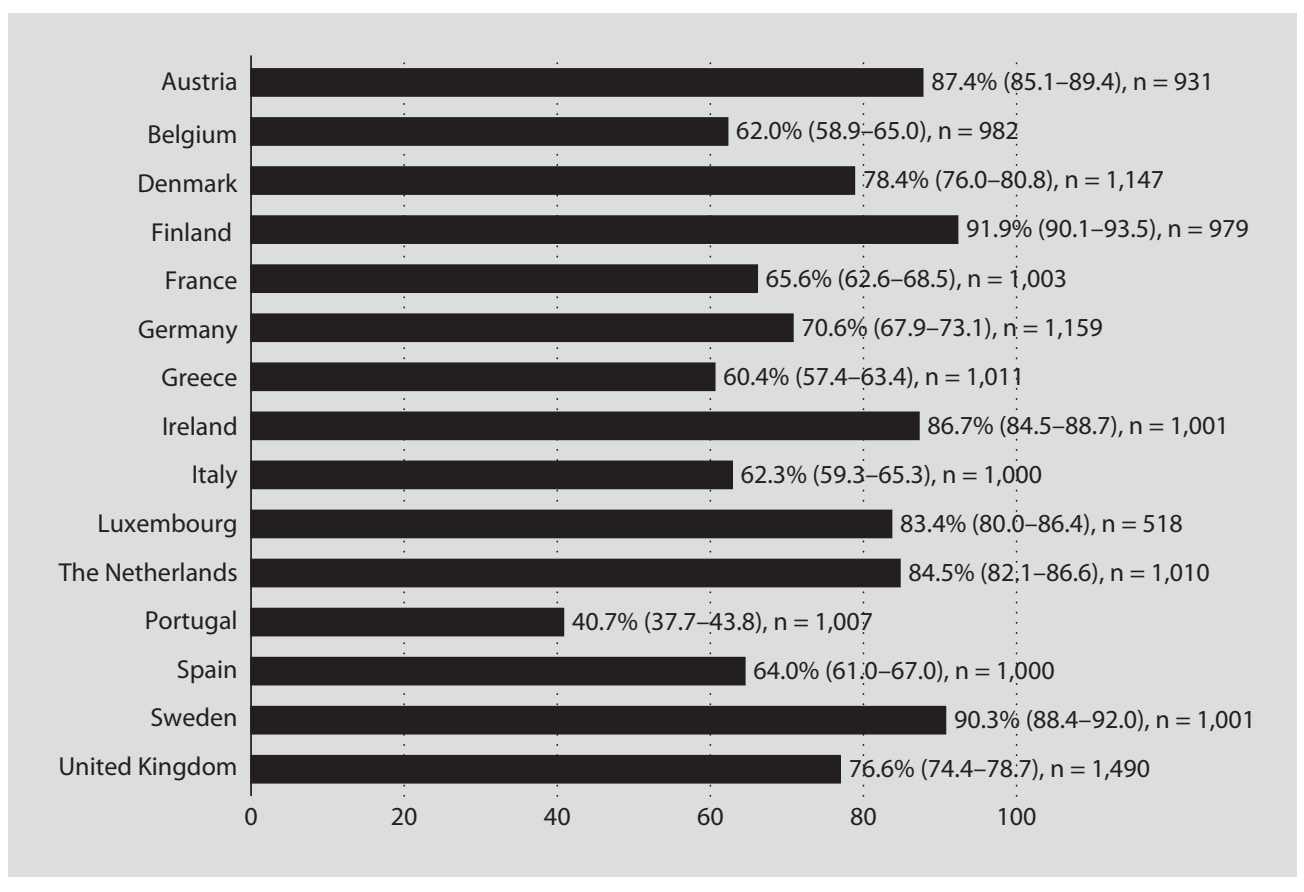

Fig. 8.9. Percentage of adult population practicing any leisure-time physical activity Source: Martinez-Gonzalez et al. [2001].

Across nations, respondents in Northern European countries reported comparably higher rates of engagement in leisure-time physical activity than respondents in Southern European countries. This has been referred to as the North-South gradient of leisure-time physical activity in Europe [Martinez-Gonzalez et al., 2001].

In 2002, D.G. Sanco of the European Commission collected Eurobarometer data on physical activity across the 15 member states. Physical activity was assessed with the short form of the IPAQ (last 7 days' version). The IPAQ allows calculating METs in order to quantify the amount of physical activity. METs represent multiples of the resting metabolic rate. A MET-hour is computed by multiplying the MET score of an activity by the hours performed. With the IPAQ short-form, physical activity is assessed across the different domains. Data were gathered by face-to-face interviews, the sample size was 1,000 respondents in each nation, and the average response rate was 54.6\%. Results were reported in median METs per week (MET-h/week). Men reported higher MET-h/week than women (28.4 for men, 23.1 for women), and MET-h/week declined with age (33.7 for respondents age 15-24, 14.0 for respondents 65 years of age and older). Reported MET-h/week increased with reported gross household income (20.1 for respondents in the lowest national gross household income quartile, 27.8 for respondents in the highest national gross household income 


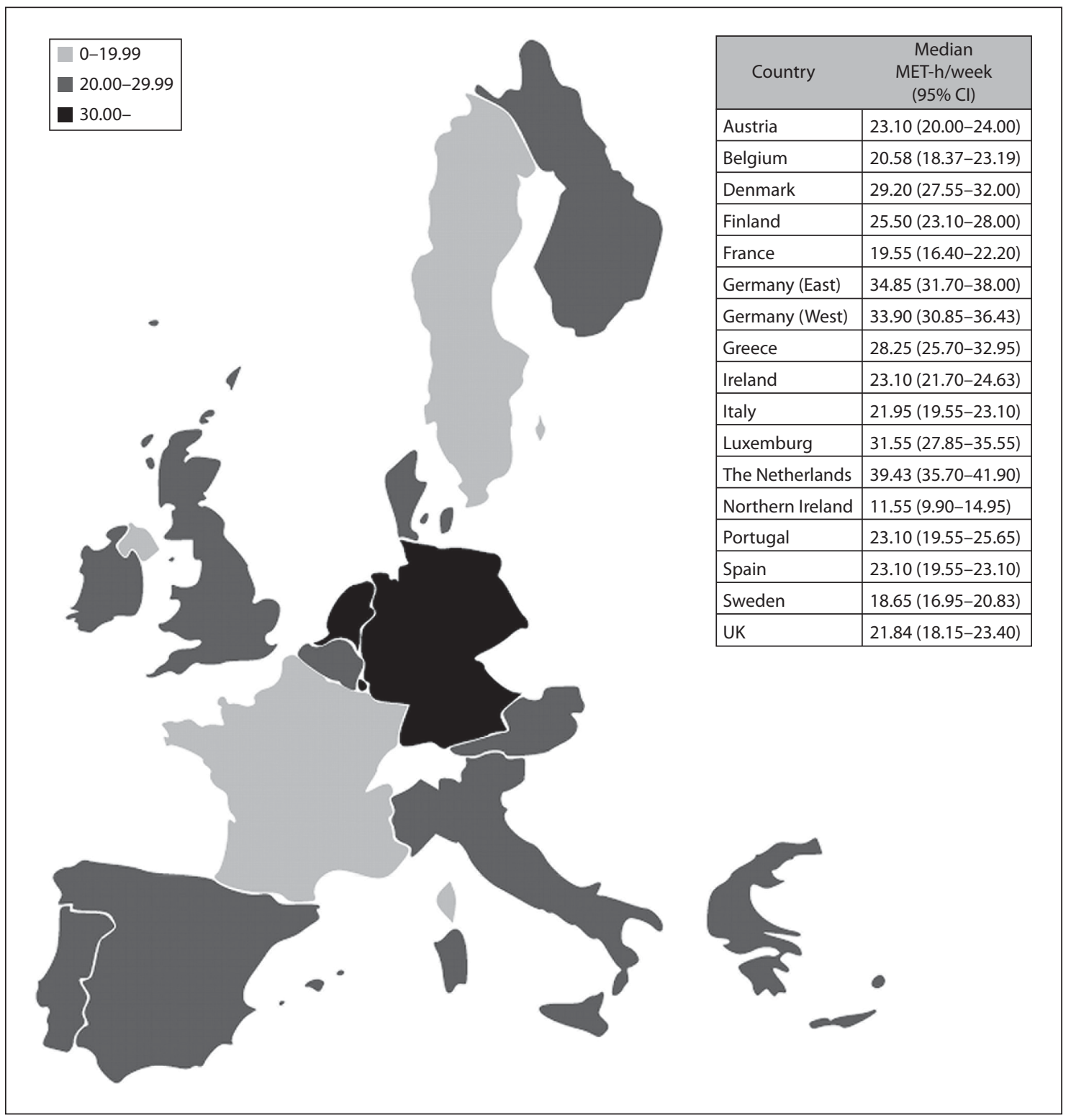

Fig. 8.10. Median MET-h/week for individuals aged 15 years and older in the member states of the European Union. Source: Rütten and Abu-Omar [2004].

quartile). Across nations (fig. 8.10), respondents in The Netherlands, Germany, and Luxembourg reported highest MET-h/week, while respondents in Northern Ireland, Sweden, and France reported lowest MET-h/week. No clear geographical trend emerged across the countries participating in the ENHR 2009 [Rütten and AbuOmar, 2004]. 
In 2004, Eurobarometer 62.0 asked if respondents engaged in exercise or practiced sport. Answer categories were ' 3 times a week or more, ' $1-2$ times a week, ' $1-3$ times a month', 'less often', or 'never'. Fieldwork was carried out in the 27 member states of the European Union, two affiliated nations (Croatia, Turkey), and Northern Cyprus. In each nation, about 1,000 respondents were interviewed face-to-face. Fig. 8.11 depicts results by nation for the percentage of respondents reporting never to engage in exercise or play sport. In Portugal (66\%), Hungary (60\%), and Italy $(58 \%)$, the highest percentages of respondents never engaging in exercise or sport were found. The lowest rates were identified in Finland (4\%), Sweden (7\%), and Denmark (17\%). These results confirm the prevalent North-South gradient with regard to leisure-time physical activity in European nations. Age and educational attainment of respondents were also related to the engagement in exercise and sport. While $60 \%$ of those aged 15-24 reported to engage in exercise or sport at least one time per week, this proportion decreased to 41\% (age 25-39), 34\% (age 40-54), and $28 \%$ (age 55 and older) in the older aged brackets. While only $20 \%$ of respondents who had finished full-time education at the age of 15 years or earlier reported to engage in exercise or sport at least one time per week, this percentage increased to $32 \%$ (for respondents finishing full-time education at age 16-19) and 50\% (for respondents finishing full-time education at the age $\geq 20$ ) for those with higher levels of educational attainment [European Commission, 2004]. The social gradient regarding physical activity behavior has also been confirmed by the EUROTHINE project. On average, the rate of those reporting at least sufficient levels of activity was 24 absolute percentage points higher in the quartile with the highest educational attainment compared to the quartile with the lowest educational attainment [Demarest et al., 2007].

Some other surveys provide additional data on physical activity levels in European nations. Among others, the Special Eurobarometer 64.3 on Health and Food contained modified IPAQ questions on physical activity, and Eurobarometer 67.3 on Health and Long-Term Care in the European Union had some items regarding engagement in leisure-time physical activity. Due to differences in the wording of questions, these data are not fully comparable to the previous surveys. Thus, to this point, no crossnational data that would allow investigating time trends in physical activity behavior exist for the European Union.

\section{Children and Adolescents - Selected Findings}

Beyond the assessment of physical activity levels of adults, there have also been some efforts to generate data for subpopulations such as children, adolescents, and older people. Regarding children and adolescents, the Health Behavior among School-aged Children (HBSC) Survey of the WHO has collected four rounds of data on physical activity in the European region, the USA, and Canada in the years 2005/2006. Questions related to physical activity behavior pertained to the number of days with a minimum of 60 minutes of physical activity per week, the number of days with 


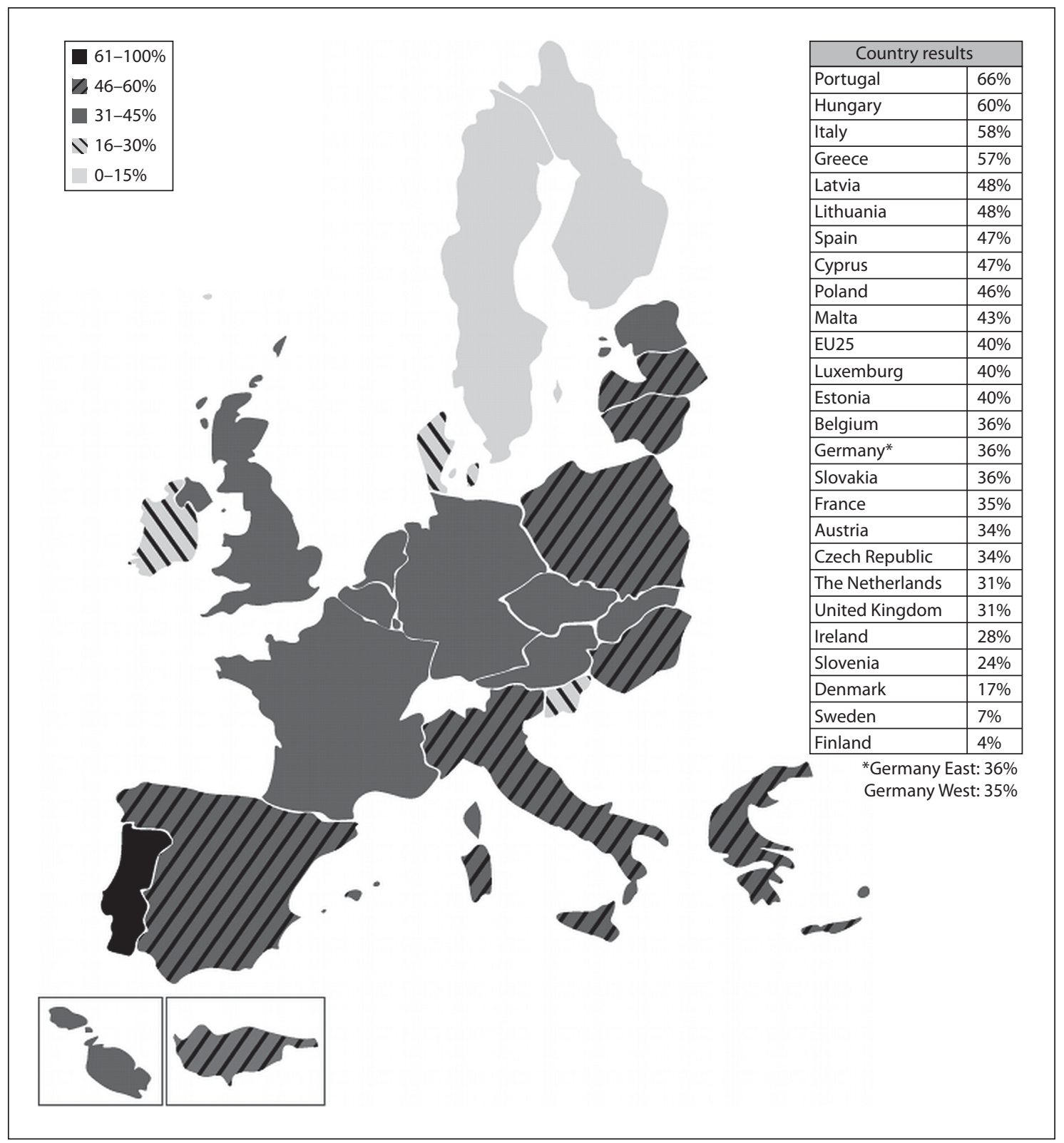

Fig. 8.11. Special Eurobarometer 213, Q48.5 'How often do you exercise or play sport?' Answer: Never. Source: European Commission, 2004.

active commuting to school (walking, biking) per week, and the number of days per week with physical education classes. These questions have been (partly) validated by Prochaska et al. [2001]. Data were collected in schools, using self-assessment questionnaires. In 40 mostly European nations, about 5,000 written questionnaires per 
nation were conducted among 11-, 13-, and 15-year-old children/adolescents. HBSC reported the percentage of children/adolescents who stated to engage in a minimum of 60 minutes of physical activity on each day of the week, which is the amount of physical activity recommended by the ACSM for children and adolescents [US Department of Health and Human Services, 2005].

Results indicate that pronounced differences in levels of daily moderate-to-vigorous physical activity exist. $26 \%$ of 11 -year-olds reported to engage in at least 60 minutes of physical activity on 7 days of the week; this percentage decreased to $20 \%$ among 13 -year-olds and 16\% among 15-year-olds. Across all age groups, a higher percentage of boys than girls reported to engage in 60 minutes of physical activity per day. Among 11-year-olds, the highest percentages were reported in Ireland (38\% for girls, $51 \%$ for boys) and Finland (37\% for girls, $48 \%$ for boys). Lowest percentages were found in Luxembourg (13\% for girls, $18 \%$ for boys) and Italy (13\% for girls, $23 \%$ for boys). Among 13-year-olds, Ireland ranked highest again, while France and Norway ranked lowest. Among 15-year-olds, the Czech Republic and Latvia ranked highest, and France and Portugal ranked lowest among European nations (fig. 8.12, 8.13) [WHO, 2008a].

\section{Elderly - Selected Findings}

For older people, there seem to be only limited cross-national data on physical activity available for Europe. The Survey of the Health, Ageing and Retirement project (SHARE) collected survey and functional test data on physical activity of individuals aged 50 years and older in 11 European nations in the years 2004 and 2006/7. Within the survey, physical activity was assessed with items on how often individuals would perform vigorous or moderate physical activity. Answer categories ranged from 'more than once a week' to 'hardly ever, or never'. Results indicate that the risk of becoming inactive is associated to increasing age and female gender. Older people from Southern European nations were more likely to become inactive compared to those of Northern European nations [Mohd Hairi et al., 2008].

\section{Outlook and Recommendations for the Future}

Recently, there have been efforts to harmonize survey questions and methods of data collection regarding physical activity and other health indicators across the European region. These efforts might, in the future, result in a European Health Monitoring System. The European Community Health Indicators (ECHI) project and the subsequent ECHI monitoring project have proposed both a core list and an extended list of health indicators to be implemented across European nations. With regard to physical activity, ECHI suggests to use, among others, the IPAQ, items on active leisure-time physical activity, and physical activity of an intensity to make a person start sweating. Eurostat has also collected a first round of data related to physical activity as part of the EHIS in 2007. EHIS assessed physical activity utilizing a modified IPAQ version. EHIS plans to collect physical activity 


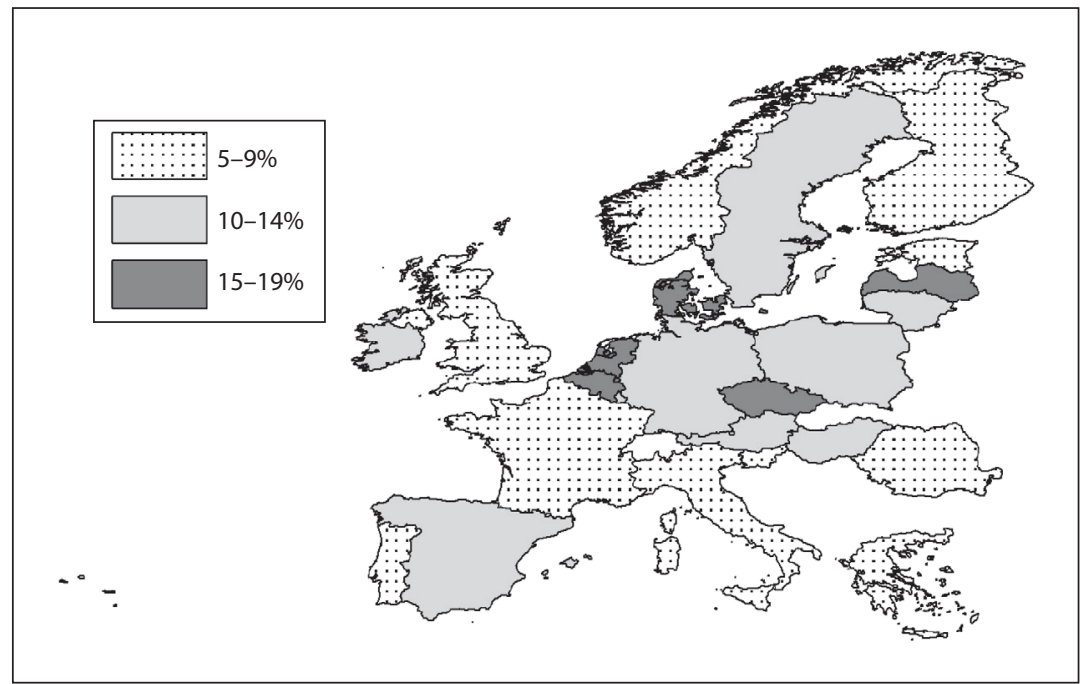

Fig. 8.12. Percentage of $\mathbf{1 5}$-year-old girls who reported at least $1 \mathrm{~h}$ of moderate-to-vigorous activity daily. Source: WHO [2008a].

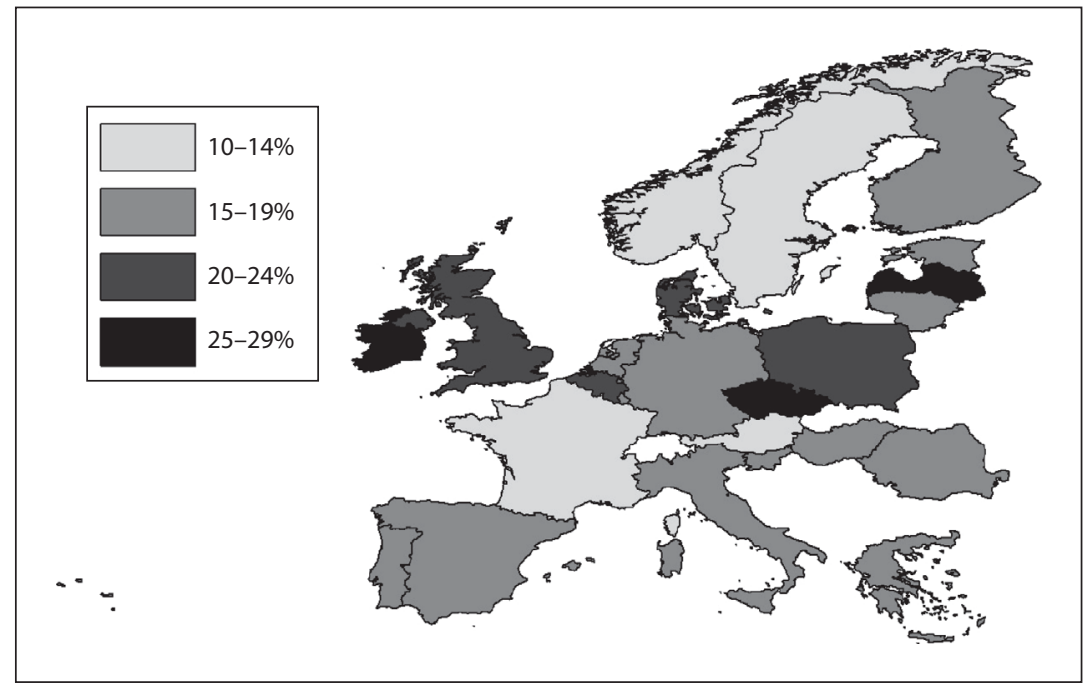

Fig. 8.13. Percentage of $\mathbf{1 5}$-year-old boys who reported at least $1 \mathrm{~h}$ of moderate-to-vigorous activity daily. Source: WHO [2008a]. 
related data biannually in all EU member states. Also, the WHO and European Commission jointly work on a project to monitor progress on improving nutrition and physical activity and to prevent obesity in the EU. This project is currently developing an inventory of existing national and cross-national datasets pertaining to the issue.

Regarding future physical activity assessment in the European Union, the abovementioned projects are of high relevance and might influence the development of policies for the promotion of physical activity. However, in order to do so, several important issues ought to be addressed: (1) Current European cross-national data suffer from a limited comparability. This is partly caused by differences in the wording of questions, even if instruments that were designed to standardize physical activity assessment (such as the IPAQ) are utilized. The Eurobarometer 64.3 and the EHIS survey for instance utilize modified IPAQ versions that yield data difficult to compare with data generated through the original IPAQ. In order to avoid surveys yielding differing or conflicting results regarding physical activity levels of populations, it might thus be important to coordinate the utilization of instruments for physical activity assessment across agencies responsible for conducting cross-national surveys in Europe. (2) Currently, methodologies employed to collect data related to physical activity vary across European surveys. This pertains to the method of data collection (e.g. face-to-face interviews, telephone interviews), response rates achieved, and routines of data cleaning, analysis, and data reporting. These factors might influence results regarding physical activity prevalence across the European region. Thus, it may be useful to agree on standards regarding the collection, analysis, and reporting of physical activity related data across surveys. (3) There is a need for cross-national survey data that enable the identification of time trends in physical activity behavior of populations. Potentially, such data could yield information on the output of policies geared at promoting physical activity on the population level and could assist in formulating and adjusting/improving such policies on national or supranational levels. While the ECHI and EHIS projects are presumably in the process of developing such surveillance systems, these efforts should be coordinated with attempts by WHO and other organizations to develop a European and Global health monitoring system. (4) Beyond these rather methodological issues, current concepts for physical activity assessment should be discussed and potentially be revised. For example, the currently employed concept of HEPA assumes that moderate or vigorous-intensity aerobic physical activity is important to promote and maintain health, independent of the domain it takes place in [Blair et al., 1996]. Following this view, survey instruments for physical activity assessment would not need to address domain-specific physical activity. The IPAQ short version is one example for such an instrument. However, a number of studies suggest that domain-specific differences in the health effects of physical activity might indeed exist, and that physical activity performed during leisure-time might potentially yield greater health benefits compared to physical activity in other domains [Oppert et al., 2006; Abu-Omar and Rütten, 2008]. 
This might imply that instruments such as the GPAQ or the IPAQ long-form that allow for assessing domain-specific levels of physical activity are better suited to monitor physical activity that is related to health outcomes on the population level. (5) Considering the current limitations of providing consistent trend data on physical activity across European nations, it might also be of interest to investigate complementary tools to monitor physical activity levels of populations, and progresses of policy efforts for promoting physical activity. In order to acquire more robust data regarding physical activity levels, some international projects are currently investigating the feasibility of objective assessments of physical activity levels as part of surveillance systems, e.g. via pedometer or accelerometer. With respect to the evaluation of the effectiveness of physical activity promotion efforts, the WHO is in the process of developing tools that allow monitoring the implementation of policies for the promotion of physical activity in different nations [WHO, 2008b]. Also, the forthcoming European Guidelines for Physical Activity Promotion will stress the importance of monitoring such policy efforts. Especially in the light of the current problems in providing consistent surveillance data on physical activity and the high relevance of policy efforts to promote physical activity, tools to monitor the progress in the implementation of such policies might be key to combating sedentary lifestyles successfully.

\subsection{Breastfeeding ${ }^{3,4}$}

Mother milk alone provides all nutrients an infant needs during the first 6 months of life. Hence, it is the ideal nourishment for this age group and no additional liquid or solid food is needed. Mother milk contains antibodies that help babies to combat disease and protect them from diarrhea and acute respiratory infections. Moreover, the immune system and response to vaccination of newborns benefit from breastfeeding [Unicef, 2009].

The WHO recommends exclusive breastfeeding for the first 6 months of life, as a public health recommendation, with introduction of complementary foods and continued breastfeeding thereafter [WHO, 2001]. A prolongation of breastfeeding after 6 months up to 2 years of age and beyond helps to ensure good nutritional status and protects against illnesses. For HIV/AIDS-positive women, breastfeeding carries the risk of mother-to-child transmission and is therefore not recommended, unless replacement feeding is not acceptable, feasible, affordable, sustainable and safe [Unicef, 2009].

3 Source of data: Protection, promotion and support of breastfeeding in Europe: pilot testing the Blueprint for Action. A project funded by the European Commission from 2005-2008.

${ }^{4}$ Putz P (Coordinating Centre), Cattaneo A (Unit for Health Services Research and International Health, IRCCS Burlo Garofolo, Trieste, Italy). 


\section{Data on Breastfeeding in European Countries}

Data has been collected for rates and trends of initiation of breastfeeding, any kind of breastfeeding at the age of 6 months, exclusive breastfeeding at 6 months and breastfeeding at 12 months for two 5-year periods: 1998-2002 and 2003-2007. Except for Cyprus and Greece, all collaborating countries in the ENHR 2009 consortium had data for at least one of the mentioned indicators at the time of data acquisition. It has to be mentioned that the definitions and methods of data collection were not harmonized across countries and thus care is needed when making comparisons between the countries. Figure legends 8.1 and 8.3 illustrate differences in the definitions of indicators. Differences in breastfeeding practices were compared across European regions also. Countries were grouped to four regions as follows. North: DK, EE, FI, LV, LT, NO, SE; West: BE, FR, IE, LU, NL, UK; Central and East: AT, CZ, DE, HU, PL, RO, SI; South: CY, GR, IT, PT, ES.

The rate of initiation of breastfeeding was almost 100\% in Norway, Lithuania, Sweden, and Denmark. Ireland was the only country with less than half (46\%) of mothers beginning to breastfeed their newborn in the most recent survey. From the countries that were able to provide a trend for this indicator, remarkable enhancements were gained in Latvia (+59\%), Ireland (+13\%), and France (+13\%). Marginal declines were observed in Austria (-3\%) and Slovenia (-1\%) (fig. 8.14).

Highest rates for any kind of breastfeeding at the age of 6 months in the most recent studies were reached in the Scandinavian countries (Norway 80\%, Sweden $72 \%$, Finland 60\%). Lowest values appeared in the UK (25\%), Belgium (25\%), and Portugal (29\%). Again, a high increase was reported from Latvia (+26\%). Minor gains were, among others, reported in Finland $(+6 \%)$ and Lithuania $(+5 \%)$. Concerning this indicator, no country that could provide a trend had a decline (fig. 8.15).

From those countries that gathered data on exclusive breastfeeding at the age of 6 months in the recent time span (2003-2007), Latvia (34\%), Lithuania (26\%), and Denmark (25\%) reported the highest rates. Low values appeared in Finland (1\%) and the UK (3\%). Only a few countries had data from both pictured time spans. Whereas the rate increased clearly in Lithuania $(+12 \%)$, Latvia $(+10 \%)$, and The Netherlands $(+6 \%)$, a remarkable decline was reported for Austria (-36\%). This, however, is due to a change of definitions between surveys (fig. 8.16).

The rate of breastfeeding at the age of 12 months was at least twice as high in Norway (36\%) and Finland (36\%) than in any other country that gathered data for this indicator. Lowest values were reported in Belgium (4\%). Each country that could provide a trend for this rate had an increase (Latvia $+9 \%$, Austria $+6 \%$, UK $+5 \%$, Lithuania $+4 \%$ ) (fig. 8.17).

Across the four described indicators, remarkable increases between the two survey periods were reported in Latvia. This is probably due to changes in survey definitions and methods.

After the completion of the dataset from which all the data described above were taken, more recent national data were published. In a national representative 


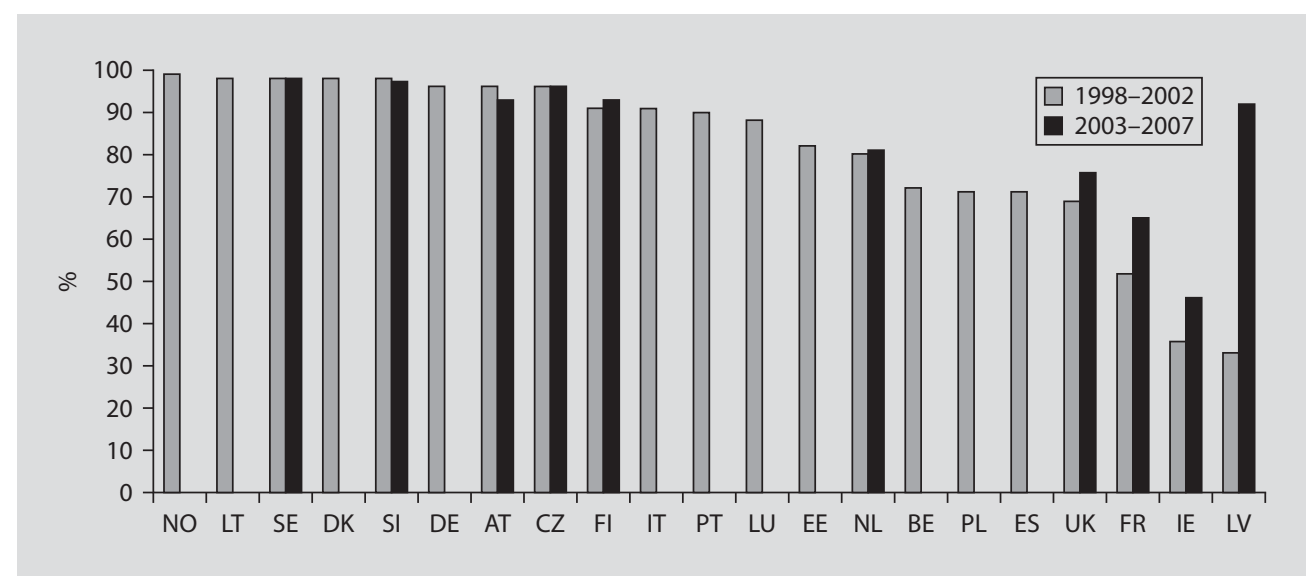

Fig. 8.14. Rates and trends of initiation of breastfeeding.

Data missing from: $\mathrm{CY}, \mathrm{GR}, \mathrm{HU}$, and $\mathrm{RO}$

$\mathrm{SI}, \mathrm{SE}$ and MT: any breastfeeding at discharge

PL and IE: exclusive breastfeeding at discharge

ES, EE and LV: any breastfeeding at six weeks

FI: any breastfeeding at age less than 1 month

NL: initiation of exclusive breastfeeding

All other countries: initiation of any breastfeeding.

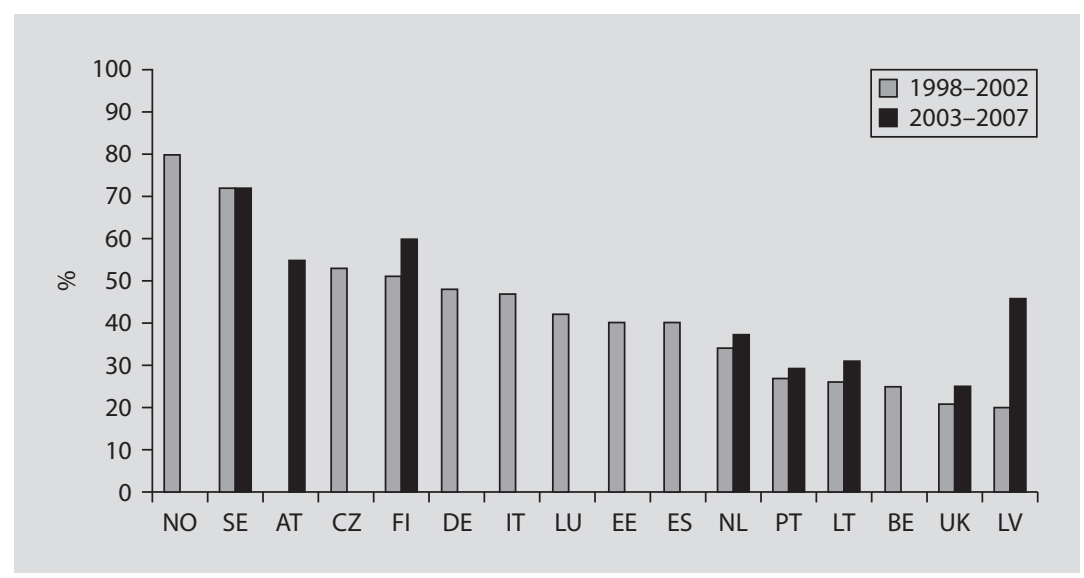

Fig. 8.15. Rates and trends of any breastfeeding at the age of 6 months. Data missing from DK, FR, $\mathrm{GR}, \mathrm{HU}, \mathrm{IE}, \mathrm{PL}, \mathrm{RO}, \mathrm{SI}$. 


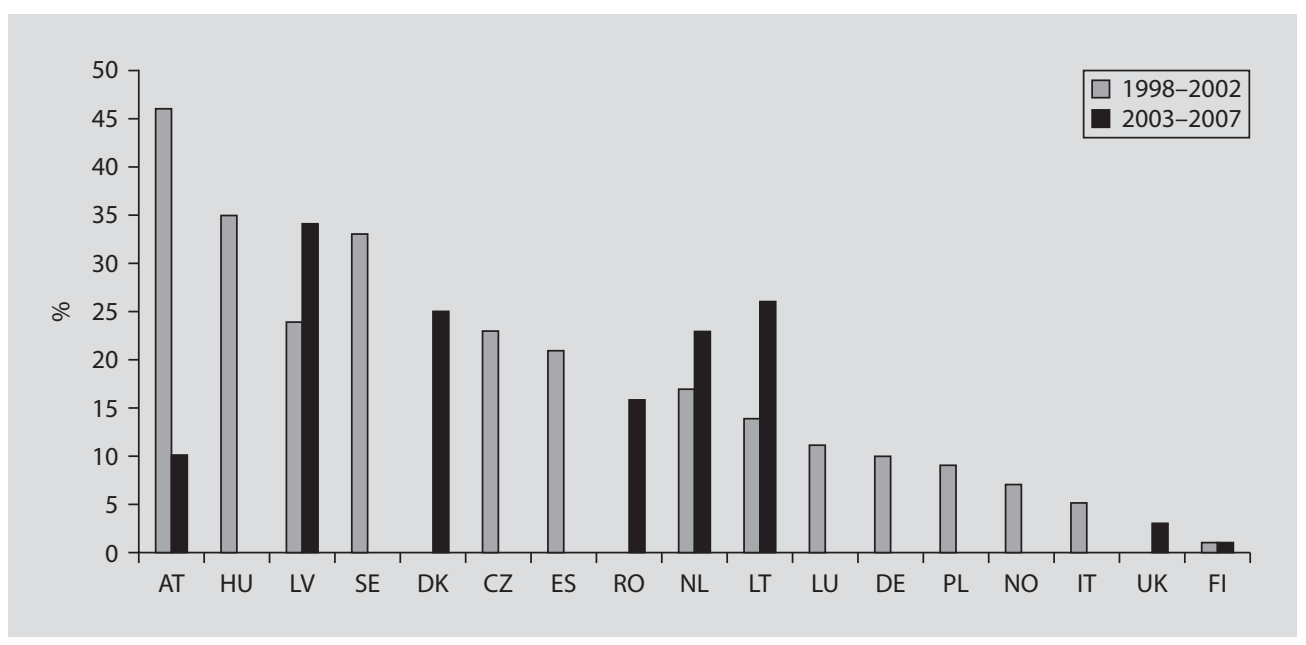

Fig. 8.16. Rates and trends of exclusive breastfeeding at the age of 6 months.

Exclusive breastfeeding: the infant receives only breast milk from his/her mother or a wet nurse, or expressed milk, and no other liquids or solids with the exception of drops or syrups consisting of vitamins, mineral supplements, or medicine (WHO, 2001).

Data missing from: $B E, E E$, FR, GR, IE, PT, SI

DK and SE: full breastfeeding

UK and NL (2007): exclusive breastfeeding at five months.

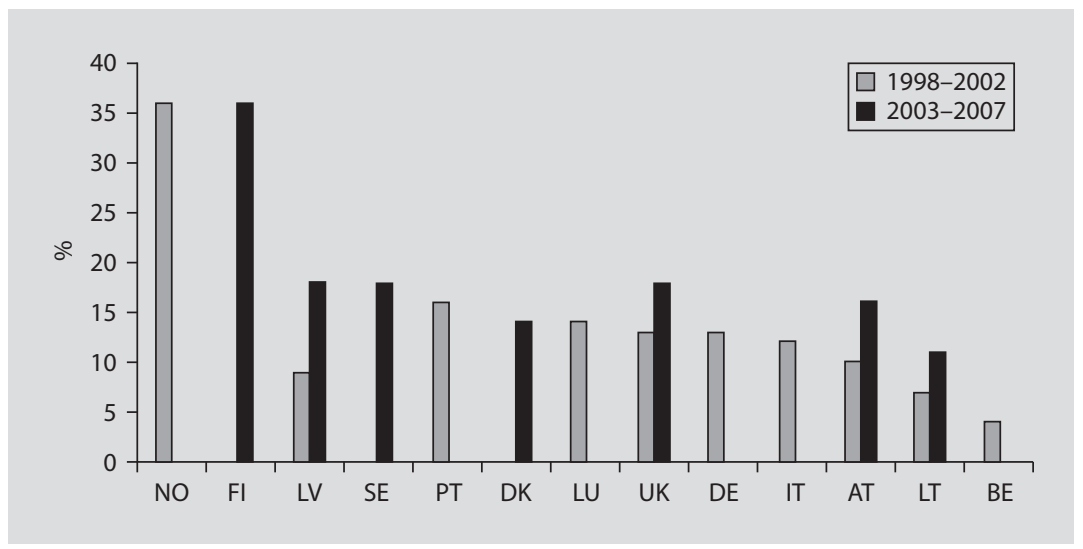

Fig. 8.17. Rates and trends of breastfeeding the age of 12 months.

Data missing from: $\mathrm{CY}, \mathrm{GR}, \mathrm{HU}$, and $\mathrm{RO}$

$\mathrm{SI}, \mathrm{SE}$ and MT: any breastfeeding at discharge

PL and IE: exclusive breastfeeding at discharge

ES, EE and LV: any breastfeeding at six weeks

Fl: any breastfeeding at age less than 1 month

$\mathrm{NL}$ : initiation of exclusive breastfeeding

All other countries: initiation of any breastfeeding. 


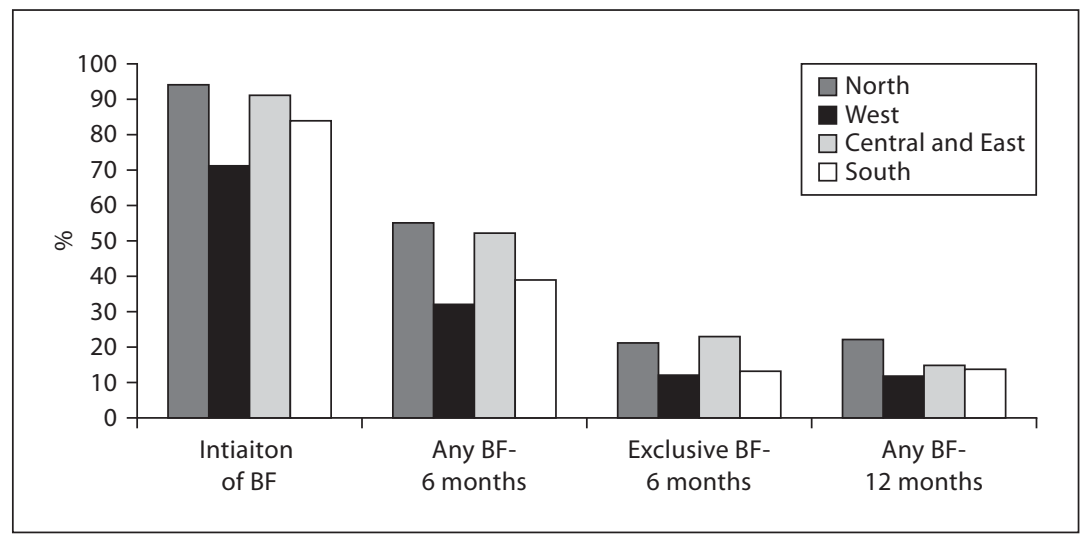

Fig. 8.18. Overview on the established regions of ENHR 2009 for four indicators of breastfeeding (BF). Mean values were calculated from the countries with available data.

Results from the most recent studies were used.

survey that was carried out in Norway in 2006-2007, the rate of initiation was $98 \%$, any breastfeeding at the age of 6 months $80 \%$ and at 12 months $46 \%$, while exclusive breastfeeding at 6 months was $9 \%$. The last two values showed an increase compared to the survey carried out 10 years before [Øverby et al., 2008a, b]. For Italy, the Italian Pediatric Association carried out a national survey in 2008. The initiation rate was $89 \%$, the rate of any breastfeeding at the age of 6 months $52 \%$ and the one at 12 months $24 \%$, while exclusive breastfeeding at 6 months was estimated at 2\% [Navone et al., 2008]. Data for the period 2004-2005 are discussed in the Italian national report (see chapter 11) referring to the results of the 'Survey on Health Conditions' [ISTAT, 2006]. For Hungary, in a recent study carried out by the Hungarian network of midwives, following rates were reported: initiation of breastfeeding 98\%, any kind at the age of 6 months $94 \%$ and at 12 months $36 \%$. The rate of exclusive breastfeeding at the age of 6 months was 37\%. A possible explanation for the high rates reported in Hungary is the length of maternity leave, which is 3 years and thus the longest in the EU [Hungarian National Centre for Healthcare Audit and Inspection, 2008]. In Greece, several studies have been conducted after 2001 and have reported breastfeeding rates [Pechlivani et al., 2005; Theofilogiannakou et al., 2006; Bakoula et al., 2007; Ladomenou, 2007]. In the most recent one study conducted during 2004 in the town of Heraklion, at the island of Crete, breastfeeding rates in a representative sample of 1,049 mothers (representing the $29 \%$ of the total births) for overall breastfeeding were $60.7,35.3,16.7$ and $4.5 \%$ at months 1, 3, 6 and 12 and for exclusive breastfeeding 24.6, 17.2, 10.2 and 3.5\% at the same time points, respectively [Ladomenou, 2007]. Unfortunately these data were gathered with different definitions and methods and it is difficult to compare them with the previous ones. 
Figure 8.18 shows an overview on the established regions of ENHR 2009 for the four indicators as described above. With the exception of exclusive breastfeeding at the age of 6 months, the North region reached the highest values in all categories. The Central and East region had the highest rates for exclusive breastfeeding at the age of 6 months and the second highest rates in each other category. Overall, the West region had the lowest values and the South region the second lowest. 